\title{
ANALISIS GENETIK POPULASI HASIL PERSILANGAN KLON RRIM 600 DENGAN GENOTIPE PLASMA NUTFAH 1981
}

\author{
Genetic Analysis of the Population Crossing Result between RRIM 600 Clone and \\ 1981 Germ Plasm Genotypes
}

\author{
Sekar WOELAN $^{11}$, Chairun NISA ${ }^{2)}$, Tetty CHAIDAMSARI ${ }^{3)}$ dan Edy IRWANSYAH ${ }^{4)}$ \\ 1) Pusat Penelitian Karet \\ J1. Salak No. 1 Bogor 16151 Jawa Barat \\ Email: sekaryudi@yahoo.com
}

${ }^{2)}$ Departemen Agroekoteknologi, Fakultas Pertanian, Universitas Sumatera Utara

Jl. Prof. A. Sofyan No.3, Kampus USU Medan- 20155

${ }^{3)}$ PT. Matahari Kahuripan Indonesia

Jl. K. H. Wahid Hasyim 188-190 Jakarta Pusat-10250

4) Gapkindo Cabang Sumatera Utara

Kompleks Taman Elok Blok 1 No. 41/156. J1. Jendral Gatot Subroto,

Sei Sikambing-Medan, Sumatra Utara

Diterima : 21 Januari 2015 / Direvisi : 28 Juli 2015 / Disetujui : 10 Agustus 2015

\begin{abstract}
The results of genetic analysis carried out on the population of RRIM 600 with genotype of germ plasm 1981 crossing result showed that some of characters observed such as plant height, girth, barkthickness, the number of latex vessels, and production showed a high diversity among generated progenies. While for the characters of the primary branch number, the first branch height, diameter of latex vessels and timber yield have poor diversity among generated progenies. The genetic analysis also obtained that the highest value of heritability $\left(h^{2}\right)>0.5$ and genetic advance $(G A)>10 \%$ for the production of latex, plant height, girth, bark thickness, and number of latex vessels characters. That characters were controlled by additive genes and epistasis acts, so it could be used as selection criteria in rubber plant. While the highest of first branches and timber yield characters was controlled by a non additive gene action (negative overdominan), so with the character of diametre of latex vessel was controlled by a dominant gene action partly negative
\end{abstract}

Keywords: Hevea, progenies, genetic variation, heritability, gene action, genetic advance

\section{Abstrak}

Hasil analisis genetik yang dilakukan terhadap populasi hasil persilangan karet klon RRIM 600 dengan genotipe Plasma Nutfah 1981 menunjukkan bahwa, beberapa karakter yang diamati seperti tinggi tanaman, lilit batang, tebal kulit, jumlah pembuluh lateks, dan produksi karet kering menunjukkan adanya keragaman yang tinggi di antara progeni yang dihasilkan. Sedangkan untuk karakter jumlah cabang primer, tinggi cabang pertama, diameter pembuluh lateks dan produksi kayu mempunyai keragaman yang rendah di antara progeni yang dihasilkan. Dari analisis genetik yang dilakukan terlihat adanya nilai heritabilitas $\left(\mathrm{h}^{2}\right)$ dan nilai kemajuan genetik (KG) yang tinggi masingmasing $>0,5 \%$ dan $>10 \%$ yaitu pada karakter produksi lateks, tinggi tanaman, lilit batang, tebal kulit, dan jumlah pembuluh lateks. Karakter-karakter tersebut dikendalikan oleh tindak gen aditif dan epistasis, karena itu dapat digunakan sebagai kriteria seleksi pada tanaman karet. Sedangkan karakter tinggi cabang pertama dan produksi kayu dikendalikan oleh tindak gen bukan aditif (overdominan negatif), demikian halnya dengan karakter diameter pembuluh lateks dikendalikan oleh tindak gen dominan sebagian negatif.

Kata kunci: Hevea, progeni, variasi genetik, heritabilitas, tindak gen, kemajuan genetik

\section{PENDAHULUAN}

Empat siklus seleksi pada pemuliaan tanaman karet telah mencapai kemajuan yang cukup nyata. Hal ini dapat diukur dari segi peningkatan potensi tanaman untuk 
memproduksi lateks (sifat primer) dan perbaikan sifat-sifat lain penunjang produksi (sifat sekunder) seperti pertumbuhan, ketahanan terhadap penyakit, mutu lateks, dan sifat karet. Dengan demikian sasaran pembudidayaan karet tidak hanya untuk menghasilkan lateks tetapi juga produksi biomassa non lateks yang mempunyai nilai ekonomi tinggi (Azwar dan Suhendry, 1998; Woelan et al., 2001).

Upaya untuk perbaikan terhadap karakter-karakter baik lateks maupun biomassa non lateks, dapat dilakukan salah satunya melalui persilangan. Penggabungan dua individu yang digunakan sebagai induk persilangan yang mempunyai jarak genetik jauh diharapkan mampu menghasilkan keragaman yang cukup tinggi (Nurhaimi et al., 1998; Oktavia et al., 2010). Keragaman genetik merupakan sumber bagi setiap program pemuliaan tanaman, karena melalui pengelolaan yang tepat dapat menghasilkan varietas baru yang lebih baik (Welsh, 2005).

Proses seleksi akan efektif, efisien dan terarah apabila tetua yang terpilih telah diketahui karakter yang diinginkan. Sebelum menetapkan metode pemuliaan dan seleksi yang akan digunakan serta bila seleksi akan dimulai, perlu diketahui berapa besar keragaman genetik (Phoehlman dan Sleeper, 1995). Kemajuan seleksi sangat ditentukan oleh tersedianya keragaman genetik suatu populasi, tanpa adanya keragaman genetik maka tidak akan terjadi perbaikan karakter suatu tanaman (Allard, 2005). Beberapa parameter genetik yang dapat digunakan sebagai pertimbangan agar diperoleh kemajuan genetik yang besar adalah nilai variabilitas genetik, heritabilitas dan dugaan kemajuan genetik yang akan dicapai (Aidi-Daslin et al., 2008; Syukur et al., 2011; Barmawi et al., 2013).

Variasi genetik dalam suatu populasi merupakan hasil kombinasi genotipe dan pengaruh lingkungan. Proporsi variasi merupakan sumber yang penting dalam program pemuliaan karena dari jumlah variasi genetik ini diharapkan terjadi kombinasi genetik yang baru. Variasi genetik akan membantu dalam mengefisienkan kegiatan seleksi. Apabila variasi genetik dalam suatu populasi besar, ini menunjukkan individu dalam populasi beragam, sehingga peluang untuk memperoleh genotipe yang diharapkan akan besar (Bahar dan Zein, 1993).

Nilai duga heritabilitas merupakan salah satu alat ukur dalam sistem seleksi yang efisien yang dapat menggambarkan efektivitas seleksi progeni berdasarkan penampilan fenotipenya. Nilai heritabilitas yang tinggi untuk suatu karakter menggambarkan karakter tersebut lebih ditentukan oleh faktor genetik, karakter yang demikian akan lebih mudah diwariskan pada generasi berikutnya (Knight, 1979; Fehr, 1987). Nilai heritabilitas suatu sifat tergantung pada tindak gen yang mengendalikan sifat tersebut (Jain, 1982). Menurut Jain (1982) heritabilitas akan bermakna jika varian genetik didominasi oleh varians aditif, karena pengaruh aditif setiap alel akan diwariskan dari tetua kepada progeninya, sedangkan pengaruh bukan aditif (dominan dan epistasis) tidak diwariskan (Crowder, 1981; Hayward, 1990 dalam Suprapto dan Kairuddin, 2007). Nilai heritabilitas secara teoritis berkisar dari 0 sampai 1. Nilai 0 ialah bila seluruh variasi yang terjadi disebabkan oleh faktor lingkungan, sedangkan nilai 1 bila seluruh variasi disebabkan oleh faktor genetik. Dengan demikian nilai heritabilitas akan terletak antara kedua nilai ekstrim tersebut (Welsh, 2005).

Selain menggunakan nilai heritabilitas yang tinggi, juga menggunakan parameter lainnya, yaitu nilai duga kemajuan genetik yang tinggi, sebab nilai heritabilitas itu sendiri kurang memberikan gambaran sebenarnya mengenai kemajuan yang diharapkan terhadap genetik (Zen, 1995). Dengan nilai heritabilitas dan kemajuan genetik akan didapatkan gambaran terbaik mengenai kemajuan yang diharapkan dari seleksi (Rachmadi et al., 1990). Seleksi akan menunjukkan kemajuan genetik yang tinggi jika sifat yang dilibatkan dalam seleksi mempunyai variasi genetik dan heritabilitas yang tinggi.

Informasi penting parameter genetik pada variabel seleksi klon sangat diperlukan untuk mengetahui berbagai karakter yang diamati dapat dijadikan dasar dalam memilih genotipe-genotipe unggul baru yang diinginkan. Untuk mengetahui pewarisan karakter-karakter diperlukan nilai komponen ragam genetik dan heritabilitas 
untuk menentukan kemajuan genetik yang diperoleh melalui seleksi (Fehr, 1987).

Penilaian secara kuantitatif terhadap masing-masing progeni juga dilakukan pada penelitian ini dengan mengukur nilai heterosis, heterobeltiosis, dan rasio potensi. Heterosis adalah penampilan progeni F1 yang lebih baik dibandingkan dengan ratarata antara dua tetua persilangan. Sementara heterobeltiosis menunjukkan progeni yang lebih baik dari tetua terbaik dan potensi rasio untuk mengukur derajat dominasigen.

Penelitian ini bertujuan untuk mempelajari keragaman genetik, nilai heritabilitas, dan kemajuan genetik dari berbagai karakter klonal dari populasi hasil persilangan antara klon RRIM 600 dengan genotipe PN (plasma nutfah) 1546.

\section{BAHAN DAN METODE}

Penelitian ini dilaksanakan di Kebun Percobaan (turunan) dari persilangan interspesifik RRIM 600 dengan genotipe plasma nutfah IRRDB 1981 di Balai Penelitian Sungei Putih, Pusat Penelitian Karet, Kecamatan Galang, Kabupaten Deli Serdang, Sumatera Utara, dengan ketinggian tempat \pm 54 meter di atas permukaan laut. Pelaksanaan penelitian ini dilakukan pada bulan Januari 2011 sampai dengan Maret 2011.

Bahan penelitian yang digunakan berupa 25 progeni klonal hasil persilangan interspesifik dari klon RRIM 600 dengan PN 1546 sebanyak 25 progeni dan 2 tetua (RRIM 600 sebagai tetua betina dan PN 1546 sebagai tetua jantan). Perbanyakan dilakukan dengan cara okulasi. Percobaan tersebut dibangun pada tahun 2008 dan ditanam dengan jarak $5 \mathrm{~m} \quad \mathrm{x} \quad 4 \quad \mathrm{~m}$. Pengamatan dilakukan pada saat tanaman berumur dua tahun.

Penelitian ini menggunakan Rancangan Acak Kelompok (RAK) nonfaktorial yang terdiri dari 25 progeni dan 2 tetua.

Jumlah blok (ulangan) = $\quad 3$ blok

$$
\text { Jumlah plot } \quad=27 \text { plot }
$$

Jumlah tanaman per plot $=5$ tanaman

Data hasil pengamatan dianalisis dengan sidik ragam dengan model linier sebagai berikut:

$$
Y i j=\mu+\rho_{i}+\delta_{j}+\varepsilon_{i j}
$$

Keterangan:

Yij : nilai pengamatan pada blok ke-i dalam progeni ke-j

$\mu \quad$ : nilai tengah (nilai rata-rata umum)

$\rho_{\mathrm{i}} \quad$ : pengaruh blok ke-i

$\delta_{j} \quad:$ pengaruh progeni ke-j

$\varepsilon_{\mathrm{ij}} \quad$ : pengaruh galat terhadap blok ke-i pada progeni ke-j

Untuk mengetahui apakah antar progeni berbeda nyata dilakukan uji beda rataan menurut Uji Jarak Berganda Duncan atau Duncan Multiple Range Test (DMRT) pada taraf 5\% (Steel dan Torrie, 1993).

Tabel 1. Sidik ragam dan pendugaan komponen ragam

\begin{tabular}{|c|c|c|c|c|}
\hline $\begin{array}{c}\text { Sumber } \\
\text { keragaman } \\
\text { Source of } \\
\text { variation }\end{array}$ & $\begin{array}{l}\mathrm{db} \\
d f\end{array}$ & $\begin{array}{c}\text { Jumlah } \\
\text { kuadrat } \\
\text { Square } \\
\text { total }\end{array}$ & $\begin{array}{l}\text { Kuadrat } \\
\text { tengah } \\
\text { Mean } \\
\text { square }\end{array}$ & $\begin{array}{c}\text { Kuadrat } \\
\text { tengah harapan } \\
\text { Expected mean } \\
\text { square }\end{array}$ \\
\hline $\begin{array}{l}\text { Blok } \\
\text { Block }\end{array}$ & $b-1$ & $\mathrm{JK}_{\mathrm{B}}$ & $\mathrm{KT}_{\mathrm{B}}$ & $\sigma^{2}{ }^{2}+g \sigma^{2} b$ \\
\hline $\begin{array}{l}\text { Genotipe } \\
\text { Genotype }\end{array}$ & g-1 & $\mathrm{JK}_{\mathrm{G}}$ & $\mathrm{KT}_{\mathrm{G}}$ & $\sigma^{2} \mathrm{e}+\mathrm{b} \sigma^{2} \mathrm{~g}$ \\
\hline $\begin{array}{l}\text { Galat } \\
\text { Error }\end{array}$ & $(b-1)(g-1)$ & $\mathrm{JK}_{\mathrm{E}}$ & $\mathrm{KT}_{\mathrm{E}}$ & $\sigma^{2} \mathrm{e}$ \\
\hline Total & bg-1 & $\mathrm{JK}_{\text {Total }}$ & & \\
\hline
\end{tabular}

Table 1. Analysis of variance and estimation of variance component 
Keragaman Genotipe dan Fenotipe

Keragaman sifat dihitung melalui analisis sidik ragam yang dikemukakan oleh Singh dan Chaudary (1977) dalam Tempake dan Luntungan (2002) adalah sebagai berikut :

$\sigma_{g}^{2}=\frac{K T_{g}-K T_{e}}{r}$

$K T_{e}=\sigma_{e}^{2}$

$\sigma_{p}^{2}=\sigma_{g}^{2}+\sigma_{e}^{2} / r$

$K K G=\frac{\sqrt{\sigma^{2}}}{\bar{x}} \times 100 \%$

$K K F=\frac{\sqrt{\sigma_{p}^{2}}}{\bar{x}} \times 100 \%$

Keterangan :

$\mathrm{X} \quad=$ Rataan populasi

KT = Kuadrat Tengah

KKG = Koefisien Keragaman Genetik

$\mathrm{KKF}=$ Koefisien Keragaman Fenotipe

$\sigma^{2} \mathrm{~g} \quad=$ Ragam genotipe

$\sigma^{2}$ p $\quad$ Ragam fenotipe

$\sigma^{2} \mathrm{e} \quad=$ Ragam galat

$\mathrm{r} \quad=$ Ulangan

Kriteria keragaman menurut Murdaningsih, et al. (1990) dalam Tempake dan Luntungan (2002) adalah :

Rendah, apabila KKG = $\quad=<25 \%$

Sedang, apabila KKG = $\quad 25-50 \%$

Tinggi, apabila KKG = $\quad=50 \%$

Heritabilitas

Heritabilitas dari seluruh sampel dihitung dengan rumus :

$h^{2}=\frac{\sigma_{g}^{2}}{\sigma_{p}^{2}}=\frac{\sigma_{g}^{2}}{\sigma_{g}^{2}+\sigma_{e}^{2}}$

Menurut Stansfield (1991) dan Haeruman et al. (1990), kriteria heritabilitas adalah sebagai berikut :

Heritabilitas rendah $\quad=<0,2$

Heritabilitas sedang $\quad=0,2-0,5$

Heritabilitas tinggi $=>0,5$
Kemajuan Genetik

Kemajuan Genetik (KG) dapat dihitung dan diduga menurut cara sebagai berikut:

$K G=K\left(\sqrt{\left.\sigma_{p}^{2}\right)\left(h^{2}\right)}\right.$

Keterangan :

$\mathrm{K}=$ Konstanta 2,06 untuk intensitas seleksi 0,05

$\mathrm{x}=$ Nilai tengah populasi

$\mathrm{h}^{2}=$ Nilai heritabilitas

Heterosis, Heterobeltiosis, dan Derajat Dominansi (Laosuwan dan Atkins, 1977)

- Perbandingan nilai rata-rata penampilan progeni $\mathrm{F} 1$ dengan nilai rata-rata kedua tetuanya (mid-parent = $\mathrm{MP})$ dihitung melalui rumus :

Heterosis $=(\mathrm{F} 1-\mathrm{MP}) / \mathrm{MP} \times 100 \%$

- Perbandingan nilai rata-rata penampilan progeni F1 dengan nilai rata-rata tetua tertinggi (higher parent $=$ $\mathrm{HP}$ ) dihitung dengan rumus :

Heterobeltiosis $=(\mathrm{F} 1-\mathrm{HP}) / \mathrm{HP} \times 100 \%$

- Perhitungan derajat dominansi antara rata-rata penampilan $\mathrm{F} 1$ dengan MP maupun rata-rata penampilan $\mathrm{F} 1$ dengan HP dihitung dengan menggunakan rumus rasio potensi (Petr dan Frey, 1966) :

$\mathrm{hp}=(\mathrm{F} 1-\mathrm{MP}) /(\mathrm{HP}-\mathrm{MP})$

dimana :

$\mathrm{hp} \quad=$ nilai nisbah potensi

$\mathrm{F} 1=$ nilai rata-rata penampilan $\mathrm{F} 1$

MP = nilai rata-rata penampilan kedua tetuanya

$\mathrm{HP}$ = nilai rata-rata penampilan tetua tertinggi

Derajat dominansi dapat diklasifikasikan sebagai berikut :

- $\mathrm{hp}=0$, tidak terdapat dominan (aditif)

- $\mathrm{hp}=+1$ atau $\mathrm{h}=-1$, dominan lengkap positif atau dominan lengkap negatif

- $0<\mathrm{hp}<1$, dominan sebagian positif

- $-1<\mathrm{hp}<0$, dominan sebagian negatif

- $h p>1$ atau $h p<-1$, overdominan positif atau overdominan negatif 
Pengamatan Fenotipe

- Tinggi tanaman (m). Tinggi tanaman diukur dengan menggunakan alat ukur berskala yang diukur dari permukaan tanah sampai ke titik tumbuh ujung tanaman. Pengamatan dilakukan 1 kali selama penelitian.

- Jumlah cabang primer (cabang). Jumlah cabang primer dihitung pada batang utama untuk setiap tanaman. Pengamatan dilakukan 1 kali selama penelitian.

- Tinggi cabang pertama (m). Tinggi cabang pertama diukur dengan menggunakan alat ukur berskala yang diukur dari permukaan tanah sampai ke titik pangkal cabang pertama tanaman. Pengamatan dilakukan 1 kali selama penelitian.

- Lilit batang $(\mathrm{cm})$. Lilit batang diukur pada ketinggian $50 \mathrm{~cm}$ di atas permukaan tanah menggunakan meteran kain (ukuran $100 \mathrm{~cm}$ ). Pengamatan dilakukan 1 kali selama penelitian.

- Tebal kulit (mm). Kulit diambil dengan menggunakan alat pelubang kulit yang terbuat dari besi dengan diameter $1 \mathrm{~cm}$. Alat yang digunakan untuk mengukur ketebalan kulit adalah scliper meter. Contoh kulit diambil $5 \mathrm{~cm}$ di atas batas bidang penyadapan pada ketinggian 50 $\mathrm{cm}$. Untuk menghitung tebal kulit yang sebenarnya, skala yang ditunjukkan oleh scliper meter dikalikan faktor koreksi sebesar 0,5 $\mathrm{mm}$.

- Jumlah (pembuluh) dan diameter pembuluh lateks $(\mu)$. Untuk menghitung jumlah dan diameter pembuluh lateks dilakukan menurut metode Gomez et al. (1972). Fiksasi contoh kulit dilakukan dengan larutan FAA (Formalin Acetic Acid). Pembuatan preparat semi permanen: kulit yang telah difiksasi dipindahkan dan dimasukkan ke dalam larutan $\mathrm{KOH} 15 \%$ selama 1 jam, kemudian dibilas dengan akuades atau air mengalir selama 5 menit dan dikeringkan dengan kertas tisue. Selanjutnya direndam ke dalam larutan $\mathrm{HNO}_{3}$ selama 2 jam, dan dibilas lagi dengan air mengalir selama 5 menit dan dikeringkan dengan kertas tisu. Proses selanjutnya direndam dalam larutan alkohol 70\% selama 15 menit, dibilas kembali dengan akuades atau air mengalir dan dikeringkan dengan dihisap menggunakan kertas tisue agar tidak ada kandungan airnya, dan terakhir diberi pewarnaan Sudan III dengan cara direndam selama 30 menit. Preparat kemudian diiris dengan menggunakan pisau silet yang tajam dipotong membujur untuk melihat jumlah pembuluh, sedangkan untuk melihat diameter pembuluh lateks dipotong melintang. Masing-masing irisan tipis dari preparat tersebut diletakkan di gelas objek dan ditutup dengan gelas penutup (cover glass) yang sebelumnya diberikan gliserin untuk menjaga preparat itu tidak mengering. Setelah itu dilakukan pengamatan di bawah mikroskop dengan pembesaran $40 \mathrm{x}$.

- Daya hasil (g/p/s). Pengamatan daya hasil dilakukan dengan menggunakan metode testateks, yaitu dengan cara melukai kulit dengan menggunakan alat testateks agar terjadi aliran lateks. Kemudian lateks ditampung dengan menggunakan kertas saring. Produksi karet kering diukur dengan cara menimbang bobot kering lateks yang telah ditampung pada kertas saring. Bobot kering lateks ditimbang setelah lateks dikeringkan di dalam oven pada suhu $70^{\circ} \mathrm{C}$ selama 24 jam.

- Volume kayu ( $\mathrm{m}^{3} /$ pohon). Produksi kayu diukur dengan menggunakan rumus yang dikembangkan oleh Wan Razali Mohd et al. (1983) sebagai berikut:

$V_{p}=0,0435485+\left\{0,00005031 \times(L B / \pi)^{2}\right\} \times T T$

Keterangan:

$\mathrm{V}_{\mathrm{p}} \quad=$ volume pohon

LB = lilit batang

TT = tinggi tanaman

$\pi \quad=3,142$

\section{HASIL DAN PEMBAHASAN}

\section{Keragaman Genetik :}

Tinggi Tanaman (m)

Hasil uji beda rataan 25 progeni dan tetua terhadap tinggi tanaman dapat dilihat pada Tabel 2. Dari Tabel 2 terlihat bahwa tanaman paling tinggi ditemukan pada klon PN 1546 yaitu 8,60 m yang berbeda nyata terhadap progeni No. 5/G-277, 13/G-666, 15/G-776, 18/G-518, 25/G-521, 30/G-691, 
31/G-571, 33/G-876, dan 39/G-874, serta tanaman terendah terdapat pada progeni No. $25 / \mathrm{G}-521$ yaitu $5,29 \mathrm{~m}$ yang berbeda nyata terhadap progeni lainnya. Terjadinya perbedaan pertumbuhan tinggi tanaman progeni hasil persilangan kemungkinan disebabkan oleh genotipe tetua yang sifatnya heterozygous. Sebagian besar progeni mempunyai tinggi tanaman lebih rendah dibandingkan dengan rata-rata kedua tetuanya. Hal ini dapat dilihat dari nilai heterosis dan heterobeltiosisnya yang negatif, kecuali progeni No. 12/G-663 dan 16/G-451 mempunyai nilai positif yaitu masing-masing 0,71\% dan 1,19\% (Lampiran $1)$.

Progeni yang mempunyai ukuran tinggi tanaman lebih rendah dari rata-rata ke dua tetuanya disebabkan oleh adanya derajat dominansi gen. Derajat dominasi gen berkaitan erat dengan aksi dan interaksi gen yang berbeda satu dengan lainnya, sehingga mengakibatkan pola segregasi pada alel akan berbeda pula. Progeni yang mempunyai ukuran tinggi tanaman lebih rendah dari rata-rata kedua tetuanya, disebabkan oleh adanya aksi gen dominan sebagian negatif. Sementara yang mempunyai tinggi tanaman diantara ratarata kedua tetuanya, diakibatkan oleh aksi gen dominan sebagian positif seperti yang ditemukan pada progeni No. 12/G-663 dan $16 / \mathrm{G}-451$.

\section{Jumlah Cabang Primer (cabang)}

Hasil sidik ragam menunjukkan bahwa diantara progeni tidak berbeda nyata dalam hal jumlah cabang primer. Dari Tabel 3 dapat dilihat bahwa progeni yang memiliki jumlah cabang primer tertinggi pada progeni No. 20/G-441 yaitu 5,47 cabang dan terendah pada progeni No. 29/G-637 yaitu 2,40 cabang.

Walaupun tidak ada perbedaan secara statistik diantara progeni untuk karakter jumlah cabang primer, bervariasinya jumlah cabang ini juga disebabkan oleh adanya penggabungan sifat dari kedua tetuanya. Hal ini dapat dilihat dari nilai heterosis dan heterobeltiosisnya.

Nilai heterosis karakter jumlah cabang primer sebanyak 13 progeni dari total 25 progeni bernilai negatif antara $35,14 \%$ sampai $-2,70 \%$ dan 12 progeni

Tabel 2. Rata-rata tinggi tanaman dari 25 progeni dan dua tetuanya (RRIM 600, PN 1546)

Table 2. The average of plant height of 25 progenies and two parents (RRIM 600, PN 1546)

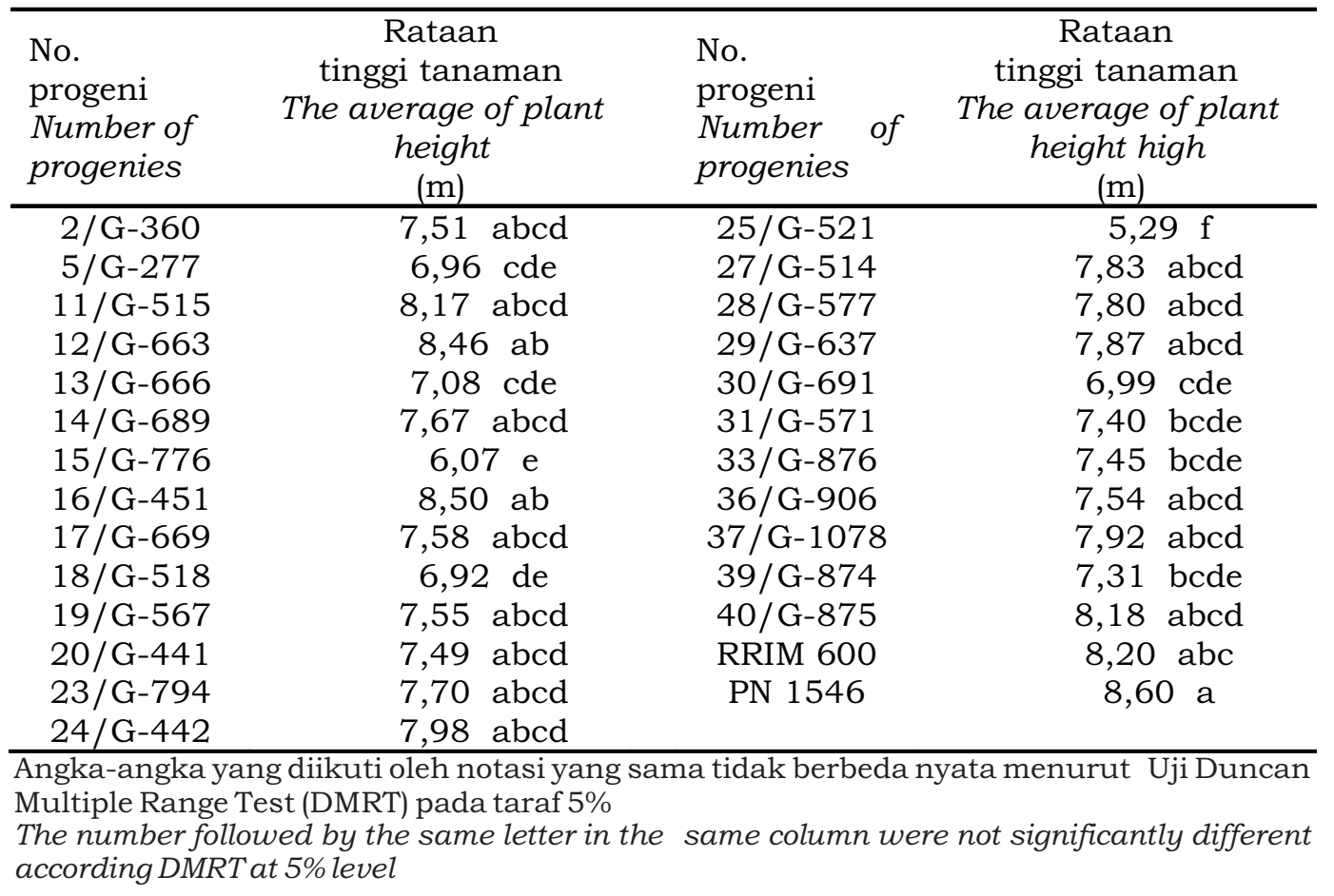


Tabel 3. Rataan jumlah cabang primer dari 25 progeni dan dua tetua (RRIM 600, PN 1546)

Table 3. The average of primary branches numbers from 25 progeneis and two parents (RRIM 600, PN 1546)

\begin{tabular}{|c|c|c|c|}
\hline $\begin{array}{l}\text { No. } \\
\text { progeni } \\
\text { Number of } \\
\text { progenies }\end{array}$ & $\begin{array}{c}\text { Rataan Jumlah Cabang } \\
\text { Primer } \\
\text { The average of primary } \\
\text { branches number } \\
\text { (cabang/branches) }\end{array}$ & $\begin{array}{l}\text { No. } \\
\text { progeni } \\
\text { Number of } \\
\text { progenies }\end{array}$ & $\begin{array}{c}\text { Rataan Jumlah } \\
\text { Cabang Primer } \\
\text { The average of } \\
\text { branches number } \\
\text { (cabang/branches) }\end{array}$ \\
\hline $2 / G-360$ & 3,53 & $25 / G-521$ & 2,58 \\
\hline $5 / G-277$ & 2,87 & $27 / G-514$ & 2,87 \\
\hline $11 / G-515$ & 3,51 & $28 / G-577$ & 4,07 \\
\hline $12 / G-663$ & 3,73 & $29 / \mathrm{G}-637$ & 2,40 \\
\hline $13 / G-666$ & 3,40 & 30/G-691 & 3,93 \\
\hline $14 / G-689$ & 3,60 & $31 / \mathrm{G}-571$ & 3,67 \\
\hline $15 / G-776$ & 4,22 & $33 / G-876$ & 4,17 \\
\hline $16 / G-451$ & 4,27 & 36/G-906 & 4,32 \\
\hline $17 / \mathrm{G}-669$ & 3,60 & $37 / G-1078$ & 4,28 \\
\hline $18 / G-518$ & 2,73 & $39 / \mathrm{G}-874$ & 3,40 \\
\hline $19 / \mathrm{G}-567$ & 3,89 & $40 / G-875$ & 4,53 \\
\hline $20 / G-441$ & 5,47 & RRIM 600 & 3,60 \\
\hline $23 / G-794$ & 3,57 & PN 1546 & 3,80 \\
\hline $24 / G-442$ & 4,67 & & \\
\hline
\end{tabular}

lainnya mempunyai nilai positif yaitu antara 0,81\%-47,84\% yang dapat pada Lampiran 1 . Hal ini menunjukkan bahwa, sebagian progeni mempunyai jumlah cabang lebih sedikit dari rata-rata kedua tetuanya dan sebagian progeni mempunyai jumlah cabangnya di antara kedua induknya. Dari 12 progeni yang mempunyai jumlah cabang banyak, 11 progeni menunjukkan jumlah cabang lebih besar dari pada rata-rata kedua tetuanya dengan nilai heterobeltiosis antara $2,37 \%-43,95 \%$ yang dapat dilihat pada Lampiran 1.

\section{Tinggi Cabang Pertama (m)}

Hasil uji rataan 25 progeni dan dua tetuanya sifat tinggi cabang pertama dapat dilihat pada Tabel 4. Dari Tabel 4 tersebut dapat diketahui bahwa tinggi cabang pertama tertinggi dimiliki oleh progeni No. 28/G-577 yaitu 3,3 m, sedangkan yang terendah progeni No. 5/G-277 yaitu 2,35 m. Karakter tinggi percabangan yang dimiliki oleh progeni yang dihasilkan tidak berbeda secara statistik, karena keragaman genetiknya rendah.

Seperti halnya jumlah cabang primer walaupun tidak ada perbedaan secara statistik di antara progeni untuk karakter tinggi cabang pertama, bervariasinya tinggi cabang pertama ini juga disebabkan oleh adanya penggabungan sifat dari kedua tetuanya. Hal ini dapat dilihat dari nilai heterosis dan heterobeltiosisnya.

Nilai heterosis karakter tinggi percabangan menunjukkan bahwa, sebanyak 20 progeni bernilai negatif, yaitu antara $-22,95 \%$ sampai $-0,66 \%$, sedangkan 5 progeni lainnya mempunyai nilai positif, yaitu antara $0,66 \%-8,20 \%$. Hal ini menunjukkan bahwa, sebagian besar progeni mempunyai tinggi percabangan pertama lebih rendah dari rata-rata kedua tetuanya, kecuali 4 progeni yaitu progeni No 12/G-663, 14/G-689, 27/G-514 dan 28/G577.

Nilai heterobeltiosis 21 progeni bersifat negatif, antara -23,95 sampai -0,65, sedangkan 4 progeni lainnya mempunyai nilai positif, yaitu antara $1,62 \%-6,80 \%$. Hal ini memberikan indikasi bahwa, ada 4 progeni mempunyai sifat tinggi cabang pertamanya lebih tinggi dari rata-rata tetua yang mempunyai nilai tinggi.

Berdasarkan dari analisis genetik yang dilakukan menunjukkan bahwa, karakter pertumbuhan tinggi percabangan pertama dari progeni yang dihasilkan tidak lebih baik dari kedua induknya. 
Tabel 4. Rataan tinggi cabang pertama 25 progeni dan dua tetua (RRIM 600, PN 1546)

Table 4. The average of the first height branch of 25 progenies and two parents (RRIM 600, PN 1546)

\begin{tabular}{|c|c|c|c|}
\hline $\begin{array}{c}\text { No. } \\
\text { progeni } \\
\text { Number of } \\
\text { progenies }\end{array}$ & $\begin{array}{l}\text { Rataan tinggi cabang } \\
\text { pertama } \\
\text { The average of the first } \\
\text { branch height } \\
\text { (m) }\end{array}$ & $\begin{array}{c}\text { No. } \\
\text { progeni } \\
\text { Number of } \\
\text { progenies }\end{array}$ & $\begin{array}{l}\text { Rataan tinggi cabang } \\
\text { pertama } \\
\text { The average of the } \\
\text { first branch height } \\
\text { (m) }\end{array}$ \\
\hline $2 / G-360$ & 2,79 & $25 / G-521$ & 2,71 \\
\hline $5 / G-277$ & 2,35 & $27 / G-514$ & 3,14 \\
\hline $11 / G-515$ & 3,03 & $28 / G-577$ & 3,30 \\
\hline $12 / G-663$ & 3,17 & $29 / \mathrm{G}-637$ & 2,49 \\
\hline $13 / G-666$ & 2,56 & $30 / \mathrm{G}-691$ & 2,97 \\
\hline $14 / G-689$ & 3,15 & $31 / \mathrm{G}-571$ & 2,64 \\
\hline $15 / G-776$ & 2,43 & $33 / G-876$ & 2,99 \\
\hline $16 / G-451$ & 3,07 & 36/G-906 & 2,67 \\
\hline $17 / G-669$ & 2,60 & $37 / \mathrm{G}-1078$ & 2,85 \\
\hline $18 / G-518$ & 2,57 & $39 / \mathrm{G}-874$ & 2,46 \\
\hline $19 / G-567$ & 2,87 & $40 / G-875$ & 2,57 \\
\hline $20 / G-441$ & 2,56 & RRIM 600 & 3,01 \\
\hline $23 / G-794$ & 2,72 & PN 1546 & 3,09 \\
\hline $24 / G-442$ & 2,77 & & \\
\hline
\end{tabular}

Lilit Batang $(\mathrm{cm})$

Hasil analisis statistik menunjukkan bahwa masing-masing progeni berbeda nyata dalam hal ukuran lilit batang. Hasil uji beda rataan 25 progeni dan 2 tetua terhadap lilit batang dapat dilihat pada Tabel 5 .
Dari Tabel 5 dapat dilihat bahwa lilit batang tertinggi terdapat pada progeni No. 28/G-577 yaitu $35,56 \mathrm{~cm}$ yang berbeda nyata terhadap progeni No. 2/G-360, 5/G$277,11 / \mathrm{G}-515,13 / \mathrm{G}-666,15 / \mathrm{G}-776$, $17 / G-669,18 / G-518,24 / G-442,25 / G-521$, 27/G-514, 30/G-691, 33/G-876, 36/G-906, 37/G-1078 dan 39/G-874, dan lilit batang

Tabel 5. Rataan lilit batang 25 progeni dan dua tetua (RRIM 600, PN 1546)

Table 5. The average of girth of 25 progenies and two parents (RRIM 600, PN 1546)

\begin{tabular}{|c|c|c|c|}
\hline $\begin{array}{c}\text { No. } \\
\text { progeni } \\
\text { Number of } \\
\text { progenies }\end{array}$ & $\begin{array}{l}\text { Rataan lilit batang } \\
\text { The average of girth } \\
\text { (cm) }\end{array}$ & $\begin{array}{c}\text { No. } \\
\text { progeni } \\
\text { Number of } \\
\text { progenies }\end{array}$ & $\begin{array}{c}\text { Rataan lilit batang } \\
\text { The average of girth } \\
(\mathrm{cm})\end{array}$ \\
\hline $2 / G-360$ & $24,23 \mathrm{gh}$ & $25 / G-521$ & 16,38 i \\
\hline $5 / \mathrm{G}-277$ & $24,73 \mathrm{gh}$ & $27 / G-514$ & 27,53 cdefgh \\
\hline $11 / G-515$ & $26,26 \mathrm{eh}$ & $28 / G-577$ & 35,56 a \\
\hline $12 / G-663$ & 30,87 abcdefg & $29 / G-637$ & 30,53 abcdefg \\
\hline $13 / G-666$ & 28,60 cdefg & $30 / G-691$ & 27,67 cdefgh \\
\hline $14 / G-689$ & $34,93 \mathrm{ab}$ & $31 / \mathrm{G}-571$ & 30,10 abcdefg \\
\hline $15 / G-776$ & $20,88 \mathrm{~h}$ & $33 / \mathrm{G}-876$ & 28,34 cdefg \\
\hline $16 / G-451$ & 33,47 abc & 36/G-906 & 29,21 bcdefg \\
\hline $17 / G-669$ & $25,03 \mathrm{fgh}$ & $37 / \mathrm{G}-1078$ & 29,09 bcdefg \\
\hline $18 / G-518$ & 26,53 defgh & $39 / \mathrm{G}-874$ & 28,22 cdefg \\
\hline $19 / G-567$ & 31,40 abcdef & $40 / G-875$ & 32,90 abcd \\
\hline $20 / G-441$ & 30,13 abcdefg & RRIM 600 & 30,40 abcdefg \\
\hline $23 / G-794$ & 30,36 abcdefg & PN 1546 & 31,97 abcde \\
\hline $24 / G-442$ & 29,53 bcdefg & & \\
\hline
\end{tabular}

Angka-angka yang diikuti oleh notasi yang sama tidak berbeda nyata menurut Uji Duncan Multiple Range Test (DMRT) pada taraf 5\%

The number followed by the same letter at the same column were not significantly different according to DMRT test $5 \%$ level 
terendah terdapat pada progeni No. 25/G521 yaitu $16,38 \mathrm{~cm}$ yang berbeda nyata terhadap progeni lainnya.

Persentase nilai progeni F1 yang disebabkan heterosis mid parent (MP), higher parent (HP) dan nilai nisbah potensial (hp) dari parameter lilit batang dapat dilihat pada Lampiran 1. Nilai heterosis karakter lilit batang sebanyak 20 progeni dari total 25 progeni bernilai negatif, yaitu antara $-47,48$ $\%$ sampai $-1,01 \%$ dan hanya 5 progeni nilai positif, yaitu antara 0,69\%-14,04\%. Hal ini menunjukkan bahwa sebagian besar progeni mempunyai ukuran lilit batang lebih rendah dari rata-rata kedua tetuanya, satu progeni mempunyai ukuran diantara kedua tetuanya dan 4 progeni mempunyai ukuran di atas nilai tetua yang tertinggi. Nilai heterobeltiosis 21 progeni juga bersifat negatif, yaitu antara $-48,76 \%$ sampai $-1,78$ $\%$ dan 4 progeni lainnya mempunyai nilai positif yaitu antara 2,91\% - 11,23\%. Hal ini memberikan indikasi bahwa, ada 21 progeni mempunyai lilit batangnya lebih rendah dari kedua tetuanya sedangkan 4 progeni menunjukkan ukuran lilit batang di atas ukuran tetua jantan (PN 1546) yang tertinggi.

Sebagian besar dari progeni hasil persilangan yang mempunyai ukuran lilit batang lebih kecil dari rata-rata kedua tetuanya, diakibatkan oleh adanya aksi gen overdominan negatif. Aksi gen overdominan positif yang mengakibatkan ukuran lilit batang lebih tinggi dari tetuanya ditemukan, yaitu pada progeni No. 14/G-689, 16/G451, 28/G-577, dan 40/G-875 sedangkan aksi gen dominan sebagian positif ditemukan pada progeni No. 19/G-567 dan aksi gen dominan sebagian negatif yaitu ditemukan pada progeni No. 12/G-663 dan 29/G-637. Progeni-progeni tersebut mempunyai ukuran lilit batang diantara kedua tetuanya.

Pengaruh heterosis sifat pertumbuhan seperti halnya lilit batang mempunyai arti yang sangat penting dalam pembentukan klon unggul (Sayurandi dan Aidi-Daslin, 2011). Dari hasil analisis genetik menunjukkan adanya progeni yang mempunyai pertumbuhan di atas tetuanya. Genotipe-genotipe tersebut diharapkan dapat digunakan sebagai materi seleksi untuk klon unggul baru.

Tebal Kulit (mm)

Hasil uji beda rataan 25 progeni dan 2 tetua terhadap tebal kulit dapat dilihat pada Tabel 6.

Tabel 6. Rataan tebal kulit 25 progeni dan 2 tetua (RRIM 600, PN 1546)

Table 6. The average of barkthickness of 25 progenies and two parents (RRIM 600, PN 1546)

\begin{tabular}{|c|c|c|c|}
\hline $\begin{array}{l}\text { No. } \\
\text { progeni } \\
\text { Number of } \\
\text { progenies }\end{array}$ & $\begin{array}{l}\text { Rataan tebal kulit } \\
\text { The average of bark } \\
\text { thickness } \\
(\mathrm{mm})\end{array}$ & $\begin{array}{l}\text { No. } \\
\text { progeni } \\
\text { Number of } \\
\text { progenies }\end{array}$ & $\begin{array}{l}\text { Rataan tebal kulit } \\
\text { The average of bark } \\
\text { thickness } \\
(\mathrm{mm})\end{array}$ \\
\hline $2 / G-360$ & $2,77 \mathrm{e}$ & $25 / G-521$ & $1,92 \mathrm{f}$ \\
\hline $5 / G-277$ & $2,79 \mathrm{e}$ & $27 / G-514$ & $2,88 \mathrm{e}$ \\
\hline $11 / G-515$ & 3,35 abcde & $28 / G-577$ & 3,68 abc \\
\hline $12 / G-663$ & 3,31 abcde & $29 / \mathrm{G}-637$ & 3,18 bcde \\
\hline $13 / \mathrm{G}-666$ & 3,21 abcde & $30 / \mathrm{G}-691$ & 3,43 abcde \\
\hline $14 / G-689$ & 3,83 a & $31 / \mathrm{G}-571$ & 3,00 cde \\
\hline $15 / G-776$ & $2,91 \mathrm{de}$ & $33 / \mathrm{G}-876$ & 3,30 abcde \\
\hline $16 / G-451$ & 3,69 abc & 36/G-906 & $3,72 \mathrm{ab}$ \\
\hline $17 / G-669$ & 3,18 bcde & $37 / \mathrm{G}-1078$ & 3,03 cde \\
\hline $18 / \mathrm{G}-518$ & $2,88 \mathrm{e}$ & $39 / \mathrm{G}-874$ & 3,00 cde \\
\hline $19 / \mathrm{G}-567$ & 3,31 abcde & $40 / \mathrm{G}-875$ & 3,48 abcde \\
\hline $20 / G-441$ & 3,38 abcde & RRIM 600 & 3,11 bcde \\
\hline $23 / \mathrm{G}-794$ & 3,60 abcd & PN 1546 & 3,18 bcde \\
\hline $24 / G-442$ & 3,43 abcde & & \\
\hline \multicolumn{4}{|c|}{$\begin{array}{l}\text { Angka-angka yang diikuti oleh notasi yang sama tidak berbeda nyata menurut Uji Duncan } \\
\text { Multiple Range Test (DMRT) pada taraf } 5 \% \\
\text { (The number followed by the same letter at the same column were not significantly different } \\
\text { according to DMRT test at 5\% level) }\end{array}$} \\
\hline
\end{tabular}


Dari Tabel 6 terlihat bahwa tebal kulit tertinggi terdapat pada progeni No. 14/G689 yaitu $3,83 \mathrm{~mm}$ yang berbeda nyata terhadap progeni No. 2/G-360, 5/G-277, 15/G-776, 17/G-669, 18/G-518, 25/G-521, 27/G-514, 29/G-637, 31/G-571, 37/G1078, 39/G-874, klon RRIM 600 dan PN 1546 , dan tebal kulit terendah terdapat pada progeni No. 25/G-521 yaitu $1,92 \mathrm{~mm}$ yang berbeda nyata terhadap progeni lainnya. Bervariasinya tebal kulit dapat diketahui dari persentase nilai progeni $\mathrm{F} 1$ yang disebabkan heterosis mid parent (MP), higher parent (HP) dan nilai nisbah potensi (hp) yang dapat dilihat pada Lampiran 1.

Nilai heterosis karakter tebal kulit sebanyak 9 progeni dari total 25 progeni bernilai negatif antara - 38,95\% sampai $4,61 \%$ dan 16 progeni yang mempunyai nilai positif yaitu antara $1,11 \%-21,78 \%$. Hal ini menunjukkan bahwa, sebagian kecil yaitu 9 progeni mempunyai ukuran tebal kulit lebih rendah dari rata-rata kedua tetuanya dan 16 progeni lainnya ukurannya di atas nilai tetua yang tertinggi. Nilai heterobeltiosis 9 progeni yang dihasilkan dari hasil persilangan bersifat negatif antara $-39,62 \%$ sampai $-4,72 \%, 14$ progeni lainnya mempunyai nilai positif yaitu antara $0,94 \%$ $20,44 \%$, dan 2 progeni mempunyai ukuran tebal kulit sama dengan tetua jantan (PN 1546). Hal ini memberikan indikasi bahwa, ada 9 progeni mempunyai tebal kulit lebih rendah dari kedua tetuanya dan 14 progeni menunjukkan ukuran tebal kulit di atas ukuran ke dua tetuanya.

Ukuran tebal kulit lebih kecil dari progeni hasil persilangan dibanding ratarata kedua tetuanya, diakibatkan oleh adanya aksi gen overdominan negatif. Aksi gen overdominan positif yang mengakibatkan ukuran tebal kulitnya lebih tinggi dari tetuanya ditemukan yaitu pada 14 progeni. Aksi gen dominan lengkap positif ditemukan pada progeni No 17/G-669 dan 29/G-637 karena mempunyai ukuran tebal kulit sama dengan tetua jantan (PN 1546). Hasil analisis genetik tersebut di atas menunjukkan bahwa, pada umumnya karakter tebal kulit dari progeni hasil persilangan lebih baik dari tetuanya.

\section{Jumlah Pembuluh Lateks}

Hasil analisis statistik menunjukkan masing-masing progeni berbeda nyata dalam hal jumlah pembuluh lateks. Hasil uji beda rataan 25 progeni dan tetua terhadap jumlah pembuluh lateks dapat dilihat pada Tabel 7 .

Dari Tabel 7 dapat dilihat bahwa jumlah pembuluh lateks tertinggi terdapat pada progeni No. $28 /$ G-577 yaitu 5,17 yang berbeda nyata terhadap progeni No. 2/G360, 5/G-277, 12/G-663, 13/G-666, 16/G$451, \quad 18 / G-518,20 / G-441, \quad 25 / G-521$, 27/G-514, 30/G-691, 33/G-876, 36/G-906, klon RRIM 600 dan PN 1546, dan jumlah pembuluh lateks terendah terdapat pada progeni No. 5/G-277 dan klon PN 1546 yaitu 2,17 yang berbeda nyata terhadap progeni No. 11/G-515, 14/G-689, 15/G-776, 16/G$451, \quad 17 / G-669, \quad 19 / G-567,20 / G-441$, 23/G-794, 24/G-442, 27/G-514, 28/G-577, 29/G-637, 31/G-571, 37/G-1078, 39/G874 dan 40/G-875.

Bervariasinya jumlah pembuluh lateks dapat dilihat dari persentase nilai progeni $\mathrm{F} 1$ yang disebabkan heterosis mid parent (MP), higher parent (HP) dan nilai nisbah potensi (hp) dari parameter jumlah pembuluh lateks telah disajikan pada Lampiran 1.

Nilai heterosis karakter jumlah pembuluh lateks sebanyak 3 progeni dari total 25 progeni bernilai negatif antara $23,46 \%$ sampai $-2,99 \%$ dan 17 progeni yang mempunyai nilai positif yaitu antara $5,82 \%$ $82,36 \%$. Hal ini menunjukkan bahwa, sebagian besar progeni mempunyai ukuran jumlah pembuluh lateks lebih tinggi dari rata-rata kedua tetua yang tertinggi. Sedangkan dari nilai heterobeltiosis 8 progeni yang dihasilkan dari hasil persilangan bersifat negatif antara -38,00\% sampai $-2,29 \%$, dan 16 progeni lainnya mempunyai nilai positif yaitu antara $4,86 \%$ $47,71 \%$, dan 1 progeni mempunyai jumlah pembuluh lateks sama dengan tetua betina (RRIM 600). Hal ini memberikan indikasi bahwa sebagian besar progeni mempunyai jumlah pembuluh lateks lebih tinggi dari kedua tetuanya.

Karakter jumlah pembuluh lateks dari 16 genotipe hasil persilangan yang lebih tinggi dibanding kedua rata-rata tetuanya diakibatkan oleh adanya aksi gen overdominan positif. Aksi gen dominan sebagian positif yang mengakibatkan jumlah pembuluh lateks terletak antara jumlah 
Tabel 7. Rataan jumlah pembuluh lateks 25 progeni dan 2 tetua (RRIM 600, PN 1546) pada umur 2 tahun

Table 7. The average number of latex vessel from 25 progeneis and two parents (RRIM 600, PN 1546) at 2 years old

\begin{tabular}{|c|c|c|c|}
\hline $\begin{array}{l}\text { No. } \\
\text { progeni } \\
\text { Number of } \\
\text { progeneis }\end{array}$ & $\begin{array}{c}\text { Rataan jumlah } \\
\text { pembuluh lateks } \\
\text { The average number } \\
\text { of latex vessel }\end{array}$ & $\begin{array}{l}\text { No. } \\
\text { progeni } \\
\text { Number of } \\
\text { progeneis }\end{array}$ & $\begin{array}{c}\text { Rataan jumlah } \\
\text { pembuluh lateks } \\
\text { The average } \\
\text { number of latex } \\
\text { vessel }\end{array}$ \\
\hline $2 / G-360$ & 2,50 ef & $25 / G-521$ & 3,08 cdef \\
\hline $5 / G-277$ & $2,17 \mathrm{f}$ & $27 / G-514$ & 3,83 bcde \\
\hline $11 / G-515$ & 4,08 abcd & $28 / G-577$ & 5,17 a \\
\hline $12 / G-663$ & 3,67 bcdef & 29/G-637 & $4,92 \mathrm{ab}$ \\
\hline $13 / G-666$ & 3,50 cdef & 30/G-691 & 3,42 cdef \\
\hline 14/G-689 & 4,42 abc & $31 / \mathrm{G}-571$ & $5,00 \mathrm{ab}$ \\
\hline $15 / G-776$ & 3,42 abc & $33 / G-876$ & 2,75 def \\
\hline $16 / G-451$ & 3,83 bcde & 36/G-906 & 3,08 cdef \\
\hline 17/G-669 & $4,33 \mathrm{abc}$ & $37 / G-1078$ & 4,00 abcde \\
\hline $18 / G-518$ & 3,00 def & $39 / \mathrm{G}-874$ & 4,08 abcd \\
\hline $19 / G-567$ & 4,50 abc & $40 / G-875$ & $4,50 \mathrm{abc}$ \\
\hline $20 / G-441$ & 3,83 bcde & RRIM 600 & 3,50 cdef \\
\hline 23/G-794 & 4,33 abc & PN 1546 & $2,17 \mathrm{f}$ \\
\hline $24 / G-442$ & 4,08 abcd & & \\
\hline
\end{tabular}

Angka-angka yang diikuti oleh notasi yang sama tidak berbeda nyata menurut Uji Duncan Multiple Range Test (DMRT) pada taraf 5\%

The number by the same letter at the same column were not significantly different according to DMRT test at 5\% level

pembuluh lateks diantara kedua tetuanya yang ditemukan pada progeni No. 15/G-776, 18/G-518, 25/G-521, 30/G-691, dan 36/G906. Aksi gen dominan sebagian negatif yang mengakibatkan jumlah pembuluh lateks lebih rendah dari tetuanya ditemukan pada progeni No. 2/G-360 dan 33/G-876. Aksi gen dominan lengkap positif ditemukan pada progeni No. 13/G-666 karena mempunyai jumlah pembuluh lateks sama dengan tetua betinanya (RRIM 600). Aksi gen dominan lengkap negatif ditemukan pada progeni No 5/G-277.

Progeni dengan jumlah pembuluh lateks banyak diharapkan dapat digunakan sebagai materi seleksi untuk mendapatkan klon unggul baru. Karena produksi lateks merupakan gabungan dari peranan sejumlah karakter komponen hasil di antaranya lilit batang, tebal kulit, jumlah pembuluh lateks dan partikel karet (Goncalves et al., 2005; Woelan et al., 2014).

\section{Diameter Pembuluh Lateks $(\mathrm{m} \mu)$}

Rata-rata 25 progeni dan 2 tetua terhadap diameter pembuluh lateks dapat dilihat pada Tabel 8. Dari Tabel 8 dapat dilihat bahwa ukuran diameter pembuluh lateks tertinggi terdapat pada progeni No. 31/G-571 dan klon RRIM 600 yaitu 18,75 $\mathrm{m} \mu$ dan terendah terdapat pada progeni No.

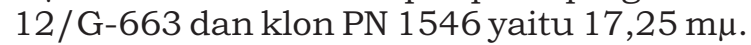
Tidak ada perbedaan secara statistik di antara progeni untuk karakter diameter pembuluh lateks, disebabkan variasi ukuran diameter rendah. Variasi yang terjadi dapat dilihat dari nilai persentase nilai progeni $\mathrm{F} 1$ yang disebabkan heterosis mid parent (MP), higher parent (HP) dan nilai nisbah potensi (hp) dari parameter diameter pembuluh lateks telah disajikan pada Lampiran 1.

Dari Tabel 8 dapat dilihat bahwa diameter pembuluh lateks tertinggi terdapat pada progeni No. 31/G-571 dan klon RRIM 
Woelan, Nisa, Chaidamsaridan Irwansyah

Tabel 8. Rataan diameter pembuluh lateks 25 progeni dan dua tetua (RRIM 600, PN 1546)

Table 8. The average diametre of latex vessel of 25 progenies and two parents (RRIM 600, PN 1546)

\begin{tabular}{|c|c|c|c|}
\hline $\begin{array}{l}\text { No. } \\
\text { progeni } \\
\text { No of } \\
\text { progenies }\end{array}$ & $\begin{array}{c}\text { Rataan diameter } \\
\text { pembuluh lateks }(\mathrm{m} \mu) \\
\text { The average diametre of } \\
\text { latex vessel }\end{array}$ & $\begin{array}{l}\text { No. progeni } \\
\text { No of } \\
\text { progenies }\end{array}$ & $\begin{array}{c}\text { Rataan diameter } \\
\text { pembuluh lateks }(\mathrm{m} \mu) \\
\text { The average diametre } \\
\text { latex vessel }\end{array}$ \\
\hline $2 / G-360$ & 17,58 & $25 / G-521$ & 17,42 \\
\hline 5/G-277 & 17,58 & $27 / G-514$ & 17,33 \\
\hline $11 / \mathrm{G}-515$ & 17,33 & $28 / G-577$ & 18,00 \\
\hline $12 / G-663$ & 17,25 & $29 / \mathrm{G}-637$ & 18,00 \\
\hline 13/G-666 & 17,58 & $30 / G-691$ & 18,25 \\
\hline $14 / G-689$ & 17,83 & $31 / G-571$ & 18,75 \\
\hline $15 / \mathrm{G}-776$ & 17,75 & $33 / G-876$ & 17,42 \\
\hline $16 / G-451$ & 18,17 & 36/G-906 & 17,67 \\
\hline $17 / \mathrm{G}-669$ & 18,17 & 37/G-1078 & 17,67 \\
\hline $18 / G-518$ & 18,67 & 39/G-874 & 17,33 \\
\hline $19 / \mathrm{G}-567$ & 17,83 & $40 / G-875$ & 17,67 \\
\hline $20 / G-441$ & 17,50 & RRIM 600 & 18,75 \\
\hline 23/G-794 & 18,08 & PN 1546 & 17,25 \\
\hline $24 / G-442$ & 17,92 & & \\
\hline
\end{tabular}

600 yaitu $18,75 \mathrm{~m} \mu$ dan terendah terdapat pada progeni No. 12/G-663 dan klon PN 1546 yaitu $17,25 \mathrm{~m} \mu$. Tidak ada perbedaan secara statistik diantara progeni untuk karakter diameter pembuluh lateks, disebabkan oleh rendahnya variasi diantara progeni. Adanya variasi tersebut dapat dilihat dari persentase nilai progeni $\mathrm{F} 1$ yang disebabkan heterosis mid parent (MP), higher parent (HP) dan nilai nisbah potensi (hp) dari parameter diameter pembuluh lateks yang dapat dilihat pada Lampiran 1.

Nilai heterosis karakter diameter pembuluh lateks sebanyak 17 progeni dari total 25 progeni bernilai negatif antara 4,17\% sampai -0,44\%. Hal ini menunjukkan bahwa, ukuran diameter pembuluh lateks di atas dari tetua jantan (PN 1546). Sebanyak 6 progeni lainnya mempunyai nilai positif yaitu antara $0,44 \%-4,17 \%$, yang artinya bahwa progeni tersebut mempunyai ukuran diameter pembuluh lateks di bawah dari tetua betinanya. Sedangkan dua progeni ukuran diameter pembuluh lateks terletak di antara rata-rata kedua induknya. Sedangkan nilai heterobeltiosis hampir secara keseluruhan 24 progeni yang dihasilkan dari hasil persilangan bersifat negatif antara $-7,58 \%$ sampai $-0,43 \%$. Hal ini memberikan indikasi bahwa ukuran diameter jumlah pembuluh lateks di antara kedua tetuanya. Hanya satu progeni (No 31/G-571) yang mempunyai ukuran diameter jumlah pembuluh lateksnya sama dengan induk betinanya yang mempunyai nilai tertinggi. Hasil analisis genetik menunjukkan bahwa, karakter diameter pembuluh lateks sebagian besar sifat negatif, yang berarti bahwa diameter pembuluh lateks progeni persilangan tidak lebih baik dari kedua induknya.

Daya Hasil (g/p/s)

Pada Tabel 9 dapat dilihat bahwa hasil karet kering uji testateks tertinggi terdapat pada progeni No. 40/G-875 yaitu $0,409 \mathrm{~g} / \mathrm{p} / \mathrm{s}$ yang berbeda nyata terhadap progeni No. 2/G-360, 5/G-277, 11/G-515, 12/G-663, 14/G-689, 15/G-776, 16/G-451, 17/G-669, 18/G-518, 20/G-441, 24/G-442, 25/G-521, 27/G-514, 28/G-577, 29/G-637, 30/G-691, 33/G-876 dan klon PN 1546. Hasil testateks terendah terdapat pada klon PN 1546 yaitu 0,068 g/p/s yang berbeda nyata terhadap progeni No. 13/G-666, 14/G-689, 19/G-567, 20/G-441, 23/G-794, 27/G-514, 28/G-577, 29/G-637, 31/G-571, 36/G-906, 37/G-1078, 39/G-874, 40/G875 dan klon RRIM 600. Besarnya variasi hasil testateks yang dihasilkan dari progeni hasil persilangan, diduga karena adanya pengaruh dari gen dominan dari salah satu tetuanya yaitu RRIM 600. 
Tabel 9. Rataan hasil testateks 25 progeni dan dua tetua (RRIM 600, PN1546) umur 2 tahun

Table 9. The average of testatex yield of 25 progenies and two parents (RRIM 600, PN 1546) on 2 years old

\begin{tabular}{|c|c|c|c|}
\hline $\begin{array}{l}\text { No. progeni } \\
\text { Number of } \\
\text { progenies }\end{array}$ & $\begin{array}{c}\text { Rataan hasil } \\
\text { testateks }(\mathrm{g} / \mathrm{p} / \mathrm{s}) \\
\text { The everage of } \\
\text { testatex yield }(\mathrm{g} / \mathrm{t} / \mathrm{t})\end{array}$ & $\begin{array}{c}\text { No. } \\
\text { progeni } \\
\text { No. of } \\
\text { progenies } \\
\end{array}$ & $\begin{array}{l}\text { Rataan hasil } \\
\text { testateks }(\mathrm{g} / \mathrm{p} / \mathrm{s}) \\
\text { The everage of } \\
\text { testatex yield }(\mathrm{g} / \mathrm{t} / \mathrm{t})\end{array}$ \\
\hline $2 / G-360$ & $0,081 \mathrm{jk}$ & $25 / G-521$ & $0,097 \quad \mathrm{ijk}$ \\
\hline $5 / G-577$ & $0,078 \mathrm{k}$ & $27 / G-514$ & 0,231 defghij \\
\hline $11 / G-515$ & 0,195 efghijk & $28 / G-577$ & 0,267 cdefg \\
\hline $12 / G-663$ & 0,208 efghijk & $29 / G-637$ & 0,261 cdefgh \\
\hline 13/G-666 & 0,291 abcdef & 30/G-691 & 0,205 efghijk \\
\hline 14/G-689 & 0,273 bcdef & $31 / \mathrm{G}-571$ & 0,291 abcdef \\
\hline $15 / G-776$ & 0,203 efghijk & $33 / G-876$ & 0,153 fghijk \\
\hline $16 / G-451$ & 0,112 hijk & 36/G-906 & 0,355 abcd \\
\hline $17 / G-669$ & 0,119 ghijk & $37 / \mathrm{G}-1078$ & $0,363 \mathrm{abcd}$ \\
\hline $18 / G-518$ & 0,147 fghijk & 39/G-874 & 0,306 abcde \\
\hline $19 / G-567$ & 0,381 abc & $40 / G-875$ & 0,409 a \\
\hline $20 / G-441$ & 0,237 defghi & RRIM 600 & $0,403 a b$ \\
\hline $23 / G-794$ & 0,318 abcde & PN 1546 & $0,068 \mathrm{k}$ \\
\hline $24 / G-442$ & 0,179 efghijk & & \\
\hline
\end{tabular}

Angka-angka yang diikuti oleh notasi yang sama tidak berbeda nyata menurut Uji Duncan Multiple Range Test (DMRT) pada taraf 5\%

(The number followed by the same letter in the same column were not significantly different according to DMRT test at $5 \%$ level)

Variasi hasil testateks diantara progeni dapat dilihat dari persentase nilai progeni $\mathrm{F} 1$ yang disebabkan heterosis mid parent (MP), higher parent (HP) dan nilai nisbah potensi (hp) dari hasil lateks telah disajikan pada Lampiran 1 .

Nilai heterosis karakter hasil testateks sebanyak 13 progeni dari total 25 progeni bernilai negatif antara $-66,88 \%$ sampai $-1,91 \%$, hal ini menunjukkan bahwa hasilnya di bawah rata-rata hasil testateks kedua tetuanya. Sebanyak 12 progeni yang mempunyai nilai positif yaitu antara $0,64 \%$ - 73,67 \% mempunyai hasil testateks di antara kedua tetuanya. Nilai heterobeltiosis hampir seluruh 24 progeni yang dihasilkan dari hasil persilangan bersifat negatif antara $-80,65 \%$ sampai $-5,46 \%$, kecuali satu progeni mempunyai nilai positif yaitu 1,49\%. Hal ini memberikan indikasi bahwa sebagian besar hasil testateks dari progeni yang dihasilkan terletak diantara kedua tetuanya, sedangkan satu progeni tersebut mempunyai hasil testateks relatif hampir sama dengan tetua betinanya (RRIM 600).

Sebanyak 16 progeni menghasilkan testateks lebih tinggi dari kedua tetuanya disebabkan oleh adanya aksi gen overdominan positif. Sedangkan aksi gen dominan sebagian positif yang mengakibatkan hasil testateks terletak di antara kedua tetuanya yang ditemukan pada progeni No 13/G-666, 14/G-689, 19/G-567, 20/G-441, 23/G-794, 28/G-577, 29/G-637, 31/G-571, 36/G-906, 37/G1078 dan 39/G-874. Aksi gen dominan sebagian negatif yang mengakibatkan produksi lebih rendah dari rata-rata kedua tetuanya ditemukan pada 13 progeni. Sedangkan aksi gen overdominan positif ditemukan pada progeni No 40/G-875 karena produksi lateks relatif hampir sama dengan tetua betinanya (RRIM 600).

Berdasarkan hasil analisis genetik, diharapkan beberapa progeni dapat digunakan sebagai materi seleksi untuk mendapatkan klon unggul yang mempunyai produksi tinggi.

\section{Hasil Kayu $\left(\mathrm{m}^{3} /\right.$ pohon)}

Hasil analisis statistik menunjukkan bahwa progeni berbeda nyata terhadap produksi kayu. Hasil uji beda rataan 25 progeni dan tetua terhadap produksi kayu dapat dilihat pada Tabel 10. 
Tabel 10. Rataan hasil kayu 25 progeni dan dua tetua (RRIM 600, PN 1546) umur 2 tahun

Table 10. The average of yield of rubber wood of 25 progeneis and 2 parents (RRIM 600, PN 1546) on two years old

\begin{tabular}{|c|c|c|c|c|c|}
\hline $\begin{array}{c}\text { No. } \\
\text { progeni } \\
\text { Number of } \\
\text { progeneis }\end{array}$ & \multicolumn{2}{|c|}{$\begin{array}{l}\text { Hasil kayu } \\
\text { (m } / \text { pohon) } \\
\text { Timber yield } \\
\left(\mathrm{m}^{3} / \text { tree }\right)\end{array}$} & $\begin{array}{c}\text { No. } \\
\text { progeni } \\
\text { Number of } \\
\text { progeneis }\end{array}$ & \multicolumn{2}{|c|}{$\begin{array}{c}\text { Hasil kayu } \\
\text { ( } \mathrm{m}^{3} / \text { pohon) } \\
\text { Timber yield } \\
\left(\mathrm{m}^{3} / \text { tree }\right)\end{array}$} \\
\hline $2 / G-360$ & 0,051853 & $\mathrm{~cd}$ & $25 / G-521$ & 0,047435 & $\mathrm{~d}$ \\
\hline $5 / G-277$ & 0,050881 & $\mathrm{~cd}$ & $27 / G-514$ & 0,056286 & abcd \\
\hline $11 / G-515$ & 0,054195 & abcd & $28 / \mathrm{G}-577$ & 0,065193 & $\mathrm{a}$ \\
\hline $12 / G-663$ & 0,059028 & $a b c$ & $29 / \mathrm{G}-637$ & 0,055874 & abcd \\
\hline $13 / G-666$ & 0,054384 & abcd & $30 / \mathrm{G}-691$ & 0,055401 & abcd \\
\hline $14 / G-689$ & 0,063163 & $a b$ & $31 / \mathrm{G}-571$ & 0,055811 & abcd \\
\hline $15 / G-776$ & 0,049883 & $\mathrm{~cd}$ & $33 / \mathrm{G}-876$ & 0,055702 & abcd \\
\hline $16 / G-451$ & 0,060954 & $a b c$ & $36 / G-906$ & 0,055362 & abcd \\
\hline $17 / G-669$ & 0,051788 & $\mathrm{~cd}$ & $37 / \mathrm{G}-1078$ & 0,055838 & abcd \\
\hline $18 / G-518$ & 0,052966 & bcd & $39 / \mathrm{G}-874$ & 0,053634 & bcd \\
\hline 19/G-567 & 0,058476 & abcd & 40/G-875 & 0,057797 & abcd \\
\hline $20 / G-441$ & 0,055552 & abcd & RRIM 600 & 0,057821 & abcd \\
\hline $23 / G-794$ & 0,056425 & abcd & PN 1546 & 0,059619 & abcd \\
\hline $24 / G-442$ & 0,056191 & abcd & & & \\
\hline
\end{tabular}

Angka-angka yang diikuti oleh notasi yang sama tidak berbeda nyata menurut Uji Duncan Multiple Range Test (DMRT) pada taraf 5\% (Figures followed by the same letter at the latter in the same column were not significantly different according to DMRT test at $5 \%$ level)

Dari Tabel 10 dapat dilihat bahwa hasil kayu tertinggi terdapat pada progeni No. $28 / \mathrm{G}-577$ yaitu $0,04380571 \mathrm{~m}^{3} /$ pohon yang berbeda nyata terhadap progeni No. 2/G-360, 5/G-277, 15/G-776, 17/G-669, 18/G-518, 25/G-521, dan 39/874. Hasil kayu terendah terdapat pada progeni No. $25 / G-521$ yaitu $0,04358837 \mathrm{~cm}^{3} /$ pohon yang berbeda nyata terhadap progeni No. 28/G-577, 12/G-663, 14/G-689, dan 16/G451. Bervariasinya karakter hasil kayu di antara progeni dapat dilihat dari nilai persentase nilai progeni $\mathrm{F} 1$ yang disebabkan heterosis mid parent (MP), higher parent (HP) dan nilai nisbah potensi (hp) dari hasil kayu dapat dilihat pada Lampiran 1.

Nilai heterosis karakter hasil kayu sebanyak 21 progeni dari total 25 progeni bernilai negatif antara $-0,30 \%$ sampai $0,004 \%$, hal ini menunjukkan bahwa hasil kayu di bawah rata-rata hasil kedua tetuanya. Sedangkan 4 progeni yang mempunyai nilai positif yaitu antara $0,04 \%$ - 0,10 \% mempunyai hasil kayu di atas kedua tetuanya. Nilai heterobeltiosis hampir seluruh 21 progeni yang dihasilkan dari hasil persilangan bersifat negatif yaitu antara $-0,43 \%$ sampai $-0,04 \%$, kecuali 4 progeni mempunyai nilai positif yaitu 0,00 $0,07 \%$. Hal ini memberikan indikasi bahwa sebagian besar hasil kayu dari progeni yang dihasilkan terletak di bawah tetuanya, sedangkan 4 progeni tersebut mempunyai hasil kayu di atas rata-rata hasil kayu tetua tertingginya (PN 1546).

Rendahnya hasil kayu dari 18 progeni dari kedua tetuanya disebabkan oleh adanya aksi gen overdominan negatif. Sedangkan aksi gen overdominan positif pada tiga progeni yaitu No. 14/G-689, 16/G451 dan 28/G-577 mengakibatkan hasil kayu lebih tinggi dari kedua tetuanya. Aksi gen dominan sebagian negatif yang mengakibatkan hasil terletak diantara kedua tetuanya yang ditemukan pada progeni No 12/G-663, 19/G-567 dan 29/G637. Aksi gen dominan lengkap positif ditemukan pada progeni No. 40/G-875 karena hasil kayu relatif hampir sama dengan induk betinanya (RRIM 600).

\section{Pendugaan Parameter Genetik}

Hasil perhitungan nilai pendugaan komponen ragam genotipe $\left(\sigma_{g}^{2}\right)$ dan ragam fenotipe $\left(\sigma_{p}^{2}\right)$, koefisien keragaman genetik 
(KKG), heritabilitas $\left(\mathrm{h}^{2}\right)$ serta nilai kemajuan genetik (KG) dari beberapa karakter yang diamati dapat dilihat pada Tabel 11 . Pentingnya nilai komponen ragam genotipe adalah untuk menunjukkan tingkat penampilan genotipe tanaman dan besarnya akan mempengaruhi KKG maupun nilai $h^{2}$. Nilai KKG berkisar antara 0,10\%-40,49\%, nilai KKF 0,12\%-44,74\%, $\mathrm{h}^{2}$ berkisar antara 0,23-0,819 dan KG berkisar antara 0,1626,76 .

Pada Tabel 11 terlihat nilai heritabilitas untuk karakter tinggi cabang pertama $(0,23)$ dan diameter pembuluh lateks $(0,29)$ termasuk ke dalam kriteria sedang. Nilai heritabilitas sedang untuk suatu karakter menggambarkan karakter tersebut sangat dipengaruhi oleh faktor lingkungan. Interaksi antara faktor genotipe dan lingkungan memiliki kemampuan yang sama kuatnya dalam mengekspresikan karakter tersebut, sehingga menyebabkan seleksi terhadap karakter-karakter tersebut kurang efektif dan karakter tersebut sangat sulit untuk diwariskan. Karakter hasil testateks $(0,82)$, tinggi tanaman $(0,69)$, lilit batang $(0,75)$, tebal kulit $(0,67)$, jumlah pembuluh lateks $(0,68)$, dan hasil kayu $(0,68)$ mempunyai nilai heritabilitas yang tinggi. Hal ini menunjukkan bahwa, karakter-karakter tersebut lebih ditentukan oleh faktor genetik tanaman dibandingkan dengan faktor lingkungan. Hasil penelitian Aidi-Daslin, et al. (2008) menunjukkan nilai heritabilitas tinggi diketemukan pada produksi lateks, tebal kulit, jumlah pembuluh lateks dan diameter lateks. Fher (1987), nilai heritabilitas yang tinggi untuk suatu karakter menggambarkan karakter tersebut lebih ditentukan oleh faktor genetik, karakter yang demikian akan lebih mudah diwariskan pada generasi berikutnya. Dari hasil penelitian ini, ketiga parameter tersebut di atas (hasil lateks, tebal kulit,

Tabel 11. Nilai pendugaan Komponen Ragam Genotipe $\left(\sigma_{\mathrm{g}}^{2}\right)$, Ragam Fenotipe $\left(\sigma_{\mathrm{p}}^{2}\right)$, Koefisien Keragaman Genetik (KKG), Koefisien Keragaman Fenotipe (KKF), Heritabilitas $\left(\mathrm{h}^{2}\right)$ dan Kemajuan Genetik (KG)

Table 11. The estimation value of genotype variance componens $\left(\sigma_{g}^{2}\right)$, Phenotype variance $\left(\sigma_{p}^{2}\right)$, Coefficient of Genetic Variance (CGV), Coefficient of Phenotype Variance $(C P V)$, Heritability $\left(h^{2}\right)$ and Genetic Advance (GA)

\begin{tabular}{|c|c|c|c|c|c|c|}
\hline $\begin{array}{l}\text { Peubah } \\
\text { Variables }\end{array}$ & $\sigma^{2} g$ & $\sigma_{p}^{2}$ & $\begin{array}{l}\text { KKG } \\
\text { CGV } \\
(\%)\end{array}$ & $\begin{array}{l}\mathrm{KKF} \\
\mathrm{CPV} \\
(\%)\end{array}$ & $\mathrm{h}^{2}$ & $\begin{array}{l}\text { KG } \\
\text { GA } \\
(\%) \\
\end{array}$ \\
\hline $\begin{array}{l}\text { Hasil testateks } \\
\text { (Testatex yield) }\end{array}$ & 0,009 & 0,011 & 40,49 & 44,74 & $0,819 \mathrm{t}$ & $76,601 \mathrm{t}$ \\
\hline $\begin{array}{l}\text { Tinggi tanaman } \\
\text { (Plant height) }\end{array}$ & 0,351 & 0,511 & 7,84 & 9,46 & $0,687 \mathrm{t}$ & $13,382 \mathrm{r}$ \\
\hline $\begin{array}{l}\text { Tinggi cabang pertama } \\
\text { (First branching height) }\end{array}$ & 0,016 & 0,070 & 4,55 & 9,48 & $0,230 \mathrm{~s}$ & $4,477 \mathrm{r}$ \\
\hline $\begin{array}{l}\text { Lilit batang } \\
\text { (Girth) }\end{array}$ & 12,671 & 16,872 & 12,40 & 14,31 & $0,751 \mathrm{t}$ & $19,188 \mathrm{r}$ \\
\hline $\begin{array}{l}\text { Tebal kulit } \\
\text { (Bark thickness) }\end{array}$ & 0,103 & 0,153 & 10,01 & 12,21 & $0,672 \mathrm{t}$ & $16,921 \mathrm{r}$ \\
\hline $\begin{array}{l}\text { Jumlah pembuluh lateks } \\
\text { (Number of latex vessel) }\end{array}$ & 0,445 & 0,653 & 17,81 & 21,57 & $0,682 \mathrm{t}$ & $30,274 \mathrm{~s}$ \\
\hline $\begin{array}{l}\text { DiameterPembuluh Lateks } \\
\text { (Diametre of latex vessel) }\end{array}$ & 0,056 & 0,194 & 1,33 & 2,47 & $0,291 \mathrm{~s}$ & $1,483 \mathrm{r}$ \\
\hline $\begin{array}{l}\text { Hasil kayu } \\
\text { (Rubber wood yield) }\end{array}$ & - & - & 0,10 & 0,12 & $0,675 \mathrm{t}$ & $0,162 \mathrm{r}$ \\
\hline
\end{tabular}

Keterangan: $\mathrm{r}$ = rendah (low)

(Note) $\quad \mathrm{s}=\operatorname{sedang}($ medium $)$

$\mathrm{t}=$ tinggi (high) 
jumlah pembuluh lateks) dapat digunakan sebagai kriteria seleksi yang lebih efektif untuk tanaman karet.

Nilai kemajuan genetik akan sangat tergantung kepada besaran ragam fenotipik dan besarnya heritabilitas. Nilai kemajuan genetik untuk karakter hasil testateks termasuk dalam kriteria tinggi $(76,60 \%)$ dan untuk jumlah pembuluh lateks tergolong sedang $(30,27 \%)$ dikendalikan oleh gen aditif pada hasil penelitian ini. Hal ini menunjukkan bahwa karakter-karakter tersebut dapat digunakan dalam seleksi. Sementara hasil penelitian Aidi-Daslin et al. (2008), yang menunjukkan kemajuan genetik tinggi ditemukan pada karakter jumlah pembuluh lateks $(50,37 \%)$. Kemajuan genetik untuk karakter tebal kulit $(46,50 \%)$, diameter pembuluh lateks $(38,22 \%)$, dan produksi $(37,68 \%)$ dikategorikan sedang. Suprapto dan Kairuddin (2007) menyatakan bahwa, kemajuan genetik yang tinggi jika sifat yang dilibatkan dalam seleksi mempunyai variasi genetik dan heritabilitas yang tinggi. Berdasarkan pendapat Burton (1952) yang mengatakan bahwa heritabilitas dan kemajuan genetik yang tinggi menunjukkan terdapat peranan yang besar tindak gen aditif dan epistasis (aditif $\mathrm{x}$ aditif dan aditif $\mathrm{x}$ dominan) yang mengendalikan sifat-sifat tersebut. Nilai heritabilitas pada karakter produksi kayu tinggi namun nilai kemajuan genetik tergolong rendah, fenomena ini terjadi oleh karena variasi genetiknya rendah. Kemungkinan karakter tersebut disebabkan pengaruh tindak gen bukan aditif (overdominan negatif).

Karakter pertumbuhan (tinggi tanaman, tinggi cabang pertama, lilit batang, tebal kulit), diameter pembuluh lateks, dan hasil kayu pada hasil penelitian ini tergolong rendah untuk nilai kemajuan genetik. Nilai kemajuan genetik yang rendah merupakan sifat-sifat yang dikendalikan oleh gen-gen bukan aditif. Gen-gen bukan aditif tidak diwariskan kepada keturunannya. Hal ini didukung oleh Tempake dan Luntungan (2002) yang menyatakan bahwa kemajuan genetik merupakan produk dari nilai-nilai diferensial seleksi, heritabilitas yang menentukan efisiensi sistem seleksi sehingga seleksi akan efektif bila nilai kemajuan genetik tinggi ditunjang oleh salah satu nilai KKG atau heritabilitas tinggi. Hayward (1990) dalam Suprapto dan Kairuddin (2007) juga menyatakan bahwa karakter yang dikendalikan oleh gen-gen bukan aditif menyebabkan kemajuan genetik yang rendah. Hal ini disebabkan pengaruh tindak gen bukan aditif tidak diwariskan dan akan lenyap semasa seleksi.

\section{KESIMPULAN}

Keragaman yang luas terdapat pada karakter hasil lateks, tinggi tanaman, lilit batang, tebal kulit, dan jumlah pembuluh lateks lebih dipengaruhi oleh faktor genetik dan peluang diturunkan lebih besar oleh karena mempunyai kriteria yang tinggi yaitu nilai heritabilitas $\left(\mathrm{h}^{2}\right)>0,5$ dan nilai kemajuan genetik (KG) $>10 \%$. Karakterkarakter tersebut dikendalikan oleh tindak gen aditif dan epistasis. Karakter tersebut di atas dapat digunakan sebagai kriteria seleksi pada tanaman karet.

Karakter tinggi cabang pertama dan produksi kayu dikendalikan oleh tindak gen bukan aditif (overdominan negatif), demikian halnya dengan karakter diameter pembuluh lateks dikendalikan oleh tindak gen dominan sebagian negatif.

\section{DAFTAR PUSTAKA}

Aidi-Daslin., Sayurandi., dan S. Woelan. 2008. Keragaman Genetik, Heritabilitas dan Korelasi Berbagai Karakter Dengan Hasil Pada Tanaman Karet. Jurnal Penelitian Karet. 26(1): 1 -9 .

Allard, R. W. 2005. Principles of Plant Breeding. John Wiley and Sons, New York.

Azwar, R., S. Woelan., Aidi-Daslin., dan I. Suhendry. 1998. Klon Harapan Seri IRR. Pros. Lok. Nasional Pemuliaan Karet dan Diskusi Nasional Prospek Karet Alam Abad 21. Medan, 8 - 9 Desember. Pusat Penelitian KaretAPPI.: $125-137$. 
Bahar, M. dan A. Zein. 1993. Parameter Genetik Pertumbuhan Tanaman, Hasil dan Komponen Hasil Jagung. Dalam Sudarmadji, R., Mardjono., dan H. Sudarmo. 2007. Variasi Genetik, Heritabilitas, dan Korelasi Genotipik Sifat-Sifat Penting Tanaman Wijen (Sesamum indicum L.). Jurnal Littri 13 (30): $88-92$.

Barmawi, M., A. Yushardi., dan Sa' diyah. 2013. Daya Waris dan Harapan Kemajuan Seleksi Karakter Agronomi Kedelai Generasi F2 Hasil Persilangan Antara Yellow Bean dan Thaicung. $J$. Agrotek Tropika. 1 (1): 20-24.

Burton, G. W. 1951. Quantitative Inheritance in Pearl Millet (Pennisitum glaucum). Agronomy Journal 43: 409417.

Crowder, L. V. 1981. Genetika Tumbuhan. Gadjah Mada University Press, Yogjakarta.

Fehr, W. R. 1987. Principle of Cultivar Development. Theory and Technique. Vol. I. MacMillan Pub. Co., New York.

Gomez, J., R. Narayanan., and K. T. Chen. 1972. Some Structural Factors Affecting the Productivity of Hevea brasiliensis Muell Arg. : I. Quantitative Determination of the Laticiferous Tissue. J. Rubb. Res. Institute Malaya. 23(3) : $193-203$.

Goncalves, P. S., A. B. B. Cardinal., R. B. Dacosta., N. Bortoletto., and L. R. L. Gouvea. 2005. Genetic Variability and Selection for Laticiferous System Characters in Hevea brasiliensis. Genetic and Molecular Biology 28 (3): 414-422.

Haeruman, K. M. A. Baihaki., D. Tohar., H. P. Anggoro. 1990. Variasi Genetik SifatSifat Tanaman Bawang Putih di Indonesia. Zuriat 1 (1) : 32-36.

Hayward, 1990 Dalam Suprapto dan Kairuddin. 2007. Variasi Genetik, Heritabilitas, Tindak Gen dan Kemajuan Genetik (Glycine Max Merrill) Pada Tanah Ultisol. Jurnal Imu-Ilmu Pertanian Indonesia. 9(20): 183-190.
Jain, J. P. 1982. Statistical Techniques in Quantitative Genetics. Tata McGrawHill Publishing Company Ltd, New Delhi.

Knight, R. 1979. Practical in Statistic and Quantitative Genetic. Australian Vice Chancelors Committe, Australia.

Laosuwan, P. and R. E. Atkins. 1977. Estimates of Combining Ability and Heterosis in Converted Exotic Shorgum. Crop. Sci. 17 (1) : 47-50.

Nurhaimi-Haris., S. Woelan., dan A. Darussamin. 1998. RAPD Genetics Variability in Plant Rubber (Hevea brasiliensis Muell. Arg) Clones. Menara Perkebunan 66(1) : 9- 19.

Oktavia, F., M. Lasminingsih., dan Kuswanhadi. 2010. Pengaruh Kondisi Daun Tanaman Karet Terhadap Keragaman Hasil Sadap Beberapa Klon Seri IRR. Jurnal Penelitian Karet 28 (2): $32-40$.

Petr, F. C. and K. J. Frey. 1966. Genotypic Correlation Dominance And Heratibility Og Quantitative Characters in Oats. Crop. Sci. 6(1) : 259 -262 .

Poehlman, J. M. 1983. Breeding Field Crops. Second ed. The Avi Publishing Company, Inc, Westport.

Rachmadi, M., N. Hermiati., Baihaki., dan R. Setiamihardja. 1990. Variasi Genetik dan Heritabilitas Komponen Hasil Galur Harapan Kedelai. Zurriat 1(1): 48 $-51$.

Sayurandi dan Aidi-Daslin. 2011. Heterosis dan Heritabilitas pada Progeni F1 Hasil Persilangan Kekerabatan Jauh Tanaman Karet. Jurnal Penelitian Karet 29(1): $1-15$.

Singh, R. K. and B. D. Chaudary. 1977. Biometrical Methods In Quantitative Genetics Analysis. Dalam Sudarmadji., R. Mardjono., dan H. Sudarmo. 2007. Variasi Genetik, Heritabilitas, dan Korelasi Genotipik Sifat-Sifat Penting Tanaman Wijen (Sesamum indicum L.). Jurnal Littri 13(3) : 88-92. 
Suprapto, N. dan Md. Kairuddin. 2007. Variasi Genetik, Heritabilitas, Tindak Gen dan Kemajuan Genetik (Glycine max Merrill) pada Tanah Ultisol. Jurnal Ilmu-Ilmu Pertanian Indonesia 9(2) : 183-190.

Stansdfield, W. D. 1991. Genetika. Edisi kedua. Erlangga, Jakarta.

Steel, R. G. D. and J. H. Torrie. 1993. Prinsip dan Prosedur Statistika (Pendekatan Biometrika). Gramedia Pustaka Utama, Jakarta.

Syukur, M., S. Sujiprihati., R. Yunianti., dan D. A. Kusumah. 2011. Pendugaan Ragam Genetik dan Heritabilitas Karakter Komponen Hasil Beberapa Genotipe Cabai. J. Agrivigor Indonesia $10(2): 148-156$.

Tempake, H. dan H. T. Luntungan. 2002. Pendugaan Parameter Genetik dan Korelasi Antar Sifat-Sifat Morfologi Kelapa (Cocos nucifera L.). Jurnal Littri 8 (3): $97-102$.

Wan Razali, Md., R. Maidin., A. Surjan and J. Md. Zain. 1983. Doubel Entry Volume Table Equation for Source RRIM 600 Series Clone of Rubber. The Malaysia Forester 46(1) : 46 - 59 .
Welsh, J. R. 2005. Fundamentals of Plant Genetics and Breeding. John Wiley and Sons, New York.

Woelan, S., Aidi-Daslin., R. Azwar., dan I. Suhendry. 2001. Keragaan Klon Karet Unggul Harapan IRR Seri 100. Pros. Lok. Nas. Pemuliaan Karet. Palembang, 5 - 6 November. Pusat Penelitian Karet.: $173-187$.

Woelan, S., Sayurandi., dan E. Irwansyah. 2014. Keragaman Genetik Tanaman Karet (Hevea braislinsis Muell Arg.) dari Hasil Persilangan Interspesifik. Jurnal Penelitian Karet 32(2) : 109 121.

Zen, S. 1995. Heritabilitas, Korelasi Genotipik dan Fenotipik Karakter Padi Gogo. Dalam Sudarmadji., R. Mardjono., dan H. Sudarmo. 2007. Variasi Genetik, Heritabilitas, dan Korelasi Genotipik Sifat-Sifat Penting Tanaman Wijen (Sesamum indicum L.). Jurnal Littri 13 (3) : 88-92. 


\begin{tabular}{|c|c|c|c|c|c|c|c|c|c|c|c|c|c|c|c|}
\hline & ILS‘6 & †ยヤ‘6 & ZS9‘O I & S8I'Z & $606^{\prime} z$ & $66 t^{\prime} \mathrm{s}$ & ZI- & $878^{\prime} 9$ I- $^{-}$ & $\varepsilon^{\prime} 8$ & I IZ‘6I & 乙ยャ‘てて & $I^{\prime} I^{-}$ & †88‘ & 6I9‘Z- & $0 t$ \\
\hline ยヤI‘ & 099‘s- & OL9‘ & $\angle L L^{\prime} \mathcal{E}^{-}$ & OEL'I I- & $809^{\prime} 6^{-}$ & $S L^{\prime} \triangleright I^{-}$ & $88 \varepsilon^{\prime} 0 z^{-}$ & $\pitchfork t \varepsilon^{\prime} 6 I^{-}$ & $\varepsilon^{-}$ & $9 Z \mathrm{CS}^{\prime} \mathrm{O} \mathrm{L}^{-}$ & 80 I'8- & $s t^{\prime} s^{-}$ & $000^{\prime} \mathrm{SI}^{-}$ & $9 \angle 6^{\circ} Z I^{-}$ & $6 \varepsilon$ \\
\hline $98 Z^{\prime} \varepsilon^{-}$ & LIL't & $\angle S 9^{\circ} \varepsilon^{-}$ & $699^{\circ} Z^{-}$ & $800^{`} 6^{-}$ & 8L L'9- & $\mathrm{S}^{-}$ & $\angle 9 L^{\prime} L^{-}$ & $\angle S S^{‘} 9^{-}$ & $8^{\prime} \mathrm{g}$ & Zદ9‘ZI & $9 \angle 9^{‘} \mathrm{SI}$ & $t^{\prime} Z^{-}$ & $\angle 06^{\prime} L^{-}$ & tIL'S- & $\angle E$ \\
\hline $6 Z t^{\circ} 9$ I & [86‘9 I & $\varepsilon 8 Z^{\prime} 8 \mathrm{I}$ & 9IS' $Z^{-}$ & عE9‘8- & $\varepsilon \varepsilon \varepsilon^{\prime} 9^{-}$ & $s^{\prime} 6^{-}$ & Z6S'E I- & 6Sナ'てI- & $Z^{\prime} 9$ & $\dashv 89^{‘} \varepsilon I$ & $\angle S L^{\prime} 9 I$ & $\varepsilon^{\prime} t$ & $9 Z \varepsilon^{\prime} 乙 I^{-}$ & $8 \varepsilon Z^{\prime} \mathrm{OI}^{-}$ & $9 \varepsilon$ \\
\hline $6 Z t^{6} t$ & $t L L^{\prime} \varepsilon$ & $876^{6} t$ & $\downarrow Z 9^{\circ} \varepsilon^{-}$ & $\dagger S \varepsilon^{6} I^{-}$ & $\varepsilon Z I^{\prime} 6^{-}$ & $\mathrm{S}^{\prime} \mathrm{I}^{-}$ & $9 \varepsilon z^{\prime} \varepsilon^{-}$ & $\angle 96^{\circ} \mathrm{I}^{-}$ & L't & $L E L ‘ 6$ & $\mathcal{E} 0 L^{\prime} Z \mathrm{I}$ & $S L ' t$ & $\tau L \mathcal{E}^{\prime} \varepsilon \mathrm{I}^{-}$ & OL $\mathcal{E}^{\prime} \mathrm{I} \mathrm{I}^{-}$ & $\varepsilon \varepsilon$ \\
\hline$\varepsilon \mapsto I ‘ t$ & 099‘9- & 0โ9‘ & $Z 8 \varepsilon^{\prime} \mathrm{I}^{-}$ & $6+8^{\prime} \mathrm{s}^{-}$ & $6 \angle t^{\prime} \varepsilon^{-}$ & $\mathrm{SZ}^{\prime} \mathrm{OI}^{-}$ & ع9ৎ‘ち I- & ๕ヤナ‘ $\varepsilon I^{-}$ & $\varepsilon^{\prime} 0^{-}$ & IZt'政- & I $18^{\circ} 0^{-}$ & $\mathrm{S}^{-}$ & $\varepsilon \subseteq 6^{\circ} \varepsilon I^{-}$ & S06' I I- & IE \\
\hline$\varepsilon \mapsto$ I’8 & Z98‘L & $290 ‘ 6$ & 8Lt゙ナ & OSt'E I- & I LZ' I I- & $\tau^{-}$ & $\varepsilon 88^{\circ} \mathcal{E}^{-}$ & $\varepsilon z 9^{\circ} \tau^{-}$ & $\varepsilon^{\prime} r$ & IZt‘E & $9\left[Z^{\prime} 9\right.$ & SO'L- & IZL'8 I- & $98 L^{\prime} 9 L^{-}$ & $0 \varepsilon$ \\
\hline 000‘ I & $000^{‘} 0$ & $\varepsilon I^{\prime \prime} \mathrm{I}$ & $t \varepsilon 8^{\circ} 0^{-}$ & t0s‘ & OOI'Z- & $\downarrow I^{-}$ & LIt‘6 I- & I9E'8 I- $^{-}$ & $\varepsilon I^{-}$ & $Z \dashv 8^{‘} 9 \mathcal{E}^{-}$ & $\mathrm{SEI} \mathrm{I}^{\prime} \mathrm{S} \mathcal{E}^{-}$ & s9' $Z^{-}$ & $88 t^{\prime} 8^{-}$ & OI $\varepsilon^{\prime} 9^{-}$ & 62 \\
\hline $98 Z^{\prime} \mathrm{SI}$ & $\varepsilon Z L^{\prime} \mathrm{G} I$ & I IO‘ $\angle$ I & $\varepsilon \angle S^{\prime} S$ & 6ZZ‘' I & $6 Z 0^{6} \triangleright I$ & $\mathrm{~s} Z^{\prime} 9$ & $96 L^{\prime} 9$ & $26 I^{\prime} 8$ & $L^{\prime} \varepsilon$ & SOI'L & O00‘O I & $\varepsilon^{-}$ & zoع`6- & $\varepsilon t I^{\prime} L^{-}$ & 87 \\
\hline I $\angle S^{6} L^{-}$ & $\downarrow \varepsilon t^{\circ} \sigma^{-}$ & $9 Z{ }^{\circ} 8-$ & 999‘ & $888^{\circ} \varepsilon I^{-}$ & OZL'I I- & $\mathrm{s} Z^{\prime} Z$ & 8I9‘ I & IS6 $\mathrm{C}$ & $\varepsilon^{\prime} 8^{-}$ & $カ \Delta \Delta^{\circ} \oplus Z^{-}$ & $\measuredangle t^{\prime} z \tau^{-}$ & $98^{\circ} z^{-}$ & $\varepsilon s 6^{\prime} 8^{-}$ & $98 L^{\prime} 9-$ & $\angle Z$ \\
\hline $000^{\prime} \mathrm{s} \mathcal{E}^{-}$ & $\varepsilon z 9^{`} 6 \varepsilon^{-}$ & IS6 $8 \mathcal{E}^{-}$ & $098^{\prime} 8 \mathrm{I}^{-}$ & $t 9 L^{\prime} 8 t$ & $s \angle t^{\prime} \angle t$ & $9^{\prime} 8-$ & $86 Z^{6} Z I^{-}$ & $8+I^{\prime} I^{-}-$ & $Z^{6}$ I I- $^{-}$ & 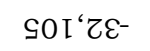 & $0\left\llcorner Z^{\prime} 0 \varepsilon^{-}\right.$ & SS'S I- & $88 t^{\prime} 8 \varepsilon^{-}$ & $\downarrow Z 0^{\prime} \angle \varepsilon^{-}$ & $\mathrm{sz}$ \\
\hline EtI'8 & $298^{\prime} \mathrm{L}$ & $290 ` 6$ & $80 I^{\prime} Z^{-}$ & Zع9'L- & $\angle 0 \varepsilon^{\prime} \mathrm{S}^{-}$ & $L^{-}$ & $99 \varepsilon^{\prime} 0 \mathrm{I}^{-}$ & 08I‘6- & L‘6 & s68‘ZZ & 9 I乙‘9Z & $I^{\prime} Z^{-}$ & $60 Z^{\prime} L^{-}$ & $000 ` \mathrm{~S}^{-}$ & $t r$ \\
\hline $000^{`} \varepsilon \mathrm{L}$ & $80 Z^{\prime} \varepsilon \mathrm{L}$ & $\angle 9 t^{\prime} \downarrow I$ & ISO' I- & 9ع0‘ $\mathrm{S}^{-}$ & $9+9^{\prime} z^{-}$ & $9 Z^{\prime} 8^{-}$ & t L6' I I- & OZ8`O I- & $\varepsilon^{6} L^{-}$ & ESO‘9- & $\downarrow I S^{\prime} \mathcal{E}^{-}$ & $\mathrm{S}^{\prime} \mathcal{E}^{-}$ & s9t'OL- & $\varepsilon \varepsilon \varepsilon^{\prime} 8^{-}$ & $\varepsilon \tau$ \\
\hline tLL'9 & $687^{\prime} 9$ & ZLt‘ & $t \succ \varepsilon^{\prime} I^{-}$ & SSL'S- & $\varepsilon 8 \varepsilon^{\prime} \varepsilon^{-}$ & $\mathrm{SZ} Z^{\prime} Z \mathrm{I}^{-}$ & ZSI' $\angle I^{-}$ & $990^{\prime} 9 \mathrm{I}^{-}$ & $L^{\prime} L I$ & $\angle \downarrow \sigma^{\circ} \varepsilon t$ & $8 \varepsilon 8^{\circ} \angle t$ & ss‘t & $\angle 06^{\circ} \mathrm{ZI}^{-}$ & Eع8‘0 I- & or \\
\hline †L L“t & 880 † & $9 b Z^{6} s$ & $\mapsto \angle Z^{\prime} 0$ & $\varepsilon 8 L^{\prime} I^{-}$ & $689^{`} 0$ & S't & OZI'L- & $206^{\circ} \mathrm{S}^{-}$ & $6^{6} \mathrm{I}$ & $89 \varepsilon^{\prime} 乙$ & SEI’S & $s Z^{\prime} \downarrow$ & $60 Z^{6} Z I^{-}$ & 6I I'O I- & $6 \mathrm{I}$ \\
\hline I $\angle S^{\prime} L^{-}$ & $\downarrow \varepsilon t^{\circ} \sigma^{-}$ & $97 t^{\circ} 8^{-}$ & $0 \varepsilon 6^{\circ} \mathrm{s}^{-}$ & 9I0' $\angle I^{-}$ & $\angle Z 6^{\circ}+I^{-}$ & $Z^{-}-$ & $878^{\prime} 9 I^{-}$ & $8 E L^{\prime} \mathrm{SI} \mathrm{I}^{-}$ & $L^{\prime} 6^{-}$ & $8 \mathrm{SI} \mathrm{I}^{\prime} 8 \mathrm{Z}^{-}$ & $9\left[z^{\prime} 9 z^{-}\right.$ & $t^{\prime} L^{-}$ & SES'6I- & 6I9“ LI- & $8 \mathrm{I}$ \\
\hline 000‘ I & $000^{‘} 0$ & $\varepsilon I I^{\prime} \mathrm{I}$ & $I+8^{\prime} L^{-}$ & $80 L^{\prime} \mathrm{IZ}$ & $\angle \mathcal{E L} L^{\prime} 6 \mathrm{I}^{-}$ & SZ' I I- & $898^{\circ} \mathrm{SI}^{-}$ & $ヤ S L^{\prime} † I^{-}$ & $\mathrm{I}^{-}$ & $\varepsilon 9 Z^{\prime} \mathrm{G}^{-}$ & $\varepsilon 0 L^{\prime} Z^{-}$ & I't & 098' I I- & Z9L‘6- & $\angle I$ \\
\hline I $\angle S^{\prime} \mathrm{SI}$ & $8 \varepsilon 0^{\prime} 9 \mathrm{I}$ & $6 Z \varepsilon^{\prime} \angle I$ & I I6'Z & $269 ‘ t$ & $\angle Z E^{\prime} L$ & $\mathrm{~s}^{\prime} 0$ & $\angle t 9^{\circ} 0^{-}$ & $999^{\circ} 0$ & L'S & $89 \varepsilon^{\prime} Z I$ & sot‘s I & $\mathrm{S}^{\prime} 0$ & E9I'I- & 06I'I & $9 \mathrm{I}$ \\
\hline$t\left[L^{\prime} 9^{-}\right.$ & I6t'8- & ZLt'L- & $\angle Z I^{\prime} \varepsilon I^{-}$ & $689^{\circ} \triangleright \mathcal{E}^{-}$ & $s+0^{‘} \varepsilon \varepsilon^{-}$ & $\mathrm{S}^{\prime} \mathrm{SI}^{-}$ & $6 S \varepsilon^{6} I Z^{-}$ & $8 Z \varepsilon^{\prime} 0 z^{-}$ & $r^{\prime} \mathrm{s}$ & Eso“I I & $\downarrow S O^{\circ} \triangleright I$ & S9'I I- & $6 I t^{\prime} 6 Z^{-}$ & $8 \varepsilon L^{\prime} \angle Z^{-}$ & $\mathrm{SI}$ \\
\hline I $\angle S^{\prime} 6$ I & Ott‘OZ & I8L'IZ & ILL't & $6 \subseteq Z^{‘} 6$ & $600^{‘} Z I$ & $s^{\prime} r$ & Z†6'I & $6 \angle Z^{\prime} \varepsilon$ & $\mathrm{I}^{-}$ & $\varepsilon 9 Z^{\prime} \mathrm{S}^{-}$ & $\varepsilon 0 L^{\prime} \tau^{-}$ & $59^{\circ} \varepsilon^{-}$ & tI $18^{\prime} \mathrm{OI}^{-}$ & $069^{`} 8^{-}$ & $t I$ \\
\hline$\angle S 8^{\circ} \mathrm{I}$ & $\varepsilon \sqcup 6^{‘} 0$ & $\angle 90^{\circ} \mathrm{Z}$ & $\varepsilon 6 乙^{\prime} \varepsilon^{-}$ & $\mathrm{I}^{\prime} \mathrm{S}^{\prime} \mathrm{O} \mathrm{I}^{-}$ & $687^{\prime} 8^{-}$ & $\mathrm{S} Z^{\prime} Z I^{-}$ & ZSI' $L I^{-}$ & $990^{\prime} 9 \mathrm{I}^{-}$ & $\varepsilon^{-}$ & $97 \mathrm{~S}^{\prime} \mathrm{OI}^{-}$ & $80 I^{\prime} 8-$ & 9‘9- & $ヤ \angle 9^{\prime} \angle I^{-}$ & tIL'S I- & $\varepsilon[$ \\
\hline$t\left[L^{\prime} t\right.$ & $880^{\circ}$ & $9 t Z^{\prime} s$ & LOt'0- & Iカt‘ $\varepsilon^{-}$ & OLO' I- & $\varepsilon$ & $689^{\prime} 乙$ & $\dashv \varepsilon \sigma^{`} \varepsilon$ & $\varepsilon^{\prime} 0$ & Z†8'I- & I I 8“0 & $\varepsilon^{\prime} 0$ & $879^{\circ} \mathrm{I}^{-}$ & †L L'O & $Z I$ \\
\hline$\angle S 8^{\circ} \mathrm{S}$ & $9 t \varepsilon^{\prime} s$ & 8IS'9 & $\downarrow \angle Z^{\prime} 9^{-}$ & $098^{\prime} \angle I^{-}$ & $\varepsilon 6 L^{\prime} \mathrm{G} \mathrm{I}^{-}$ & $\mathrm{s}^{\prime} \mathrm{O}^{-}$ & $2 t 6^{6} \mathrm{I}^{-}$ & $999^{\circ} 0^{-}$ & $6^{6} \mathrm{I}^{-}$ & Zع9'L- & SEI'S- & SI'I- & $000^{‘} \mathrm{~S}^{-}$ & $8 \varepsilon L^{\prime} Z^{-}$ & I I \\
\hline$\varepsilon \mapsto I^{\prime} O I^{-}$ & †9Z‘ Z I- & $88 Z^{6} \mathrm{I} \mathrm{I}^{-}$ & $\varepsilon 乙 \nearrow^{\prime} 8^{-}$ & 9ヤ9‘てて- & $669^{\circ} \mathrm{Oz}^{-}$ & $\mathrm{S}^{\prime} \angle \mathrm{I}^{-}$ & $8+6^{`} \varepsilon z^{-}$ & IS6‘ZZ- & $\varepsilon^{\prime} 8^{-}$ & ヤレナ゙カて- & 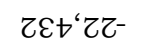 & $Z^{\prime} L^{-}$ & $0 \angle 0^{‘} 6 \mathrm{I}^{-}$ & $\varepsilon \mapsto I^{\prime} \angle I^{-}$ & $\mathrm{s}$ \\
\hline †IL'O I- & E68“Z I- & †Z6'I I- & $098^{\prime} 8^{-}$ & 0I $Z^{\prime} \triangleright Z^{-}$ & $z 0 \varepsilon^{\prime} Z \tau^{-}$ & $\mathrm{s}^{\prime} 9^{-}$ & $60 L^{‘} 6^{-}$ & sZs'8- & $L^{\prime} \mathrm{I}^{-}$ & SOI'L' & $s 6 S^{\prime} \forall$ & St゙ナ & † & S6S'0 I- & $\tau$ \\
\hline Ч & $(\%) \mathrm{dH}$ & $(\%) \mathrm{dW}$ & Ч & $(\%) \mathrm{dH}$ & $(\%) \mathrm{dW}$ & 4 & $(\%) \mathrm{dH}$ & $(\%) \mathrm{dW}$ & 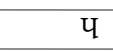 & & $(\%) \mathrm{dW}$ & Ч & $\mathrm{dH}$ & $\mathrm{dW}$ & \multirow{4}{*}{$\mathrm{ON}_{\mathrm{N}}$} \\
\hline \multicolumn{3}{|c|}{ (uw) } & \multirow{2}{*}{\multicolumn{3}{|c|}{$\begin{array}{r}\text { (யว) } \\
\text { Чานฺฺ }\end{array}$}} & \multirow{2}{*}{\multicolumn{3}{|c|}{ 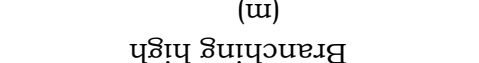 }} & \multicolumn{3}{|c|}{ (sәчगuелq/8uеqе) } & \multicolumn{3}{|c|}{ (u) } & \\
\hline \multirow{2}{*}{\multicolumn{3}{|c|}{ 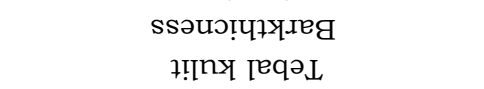 }} & & & & & & & \multicolumn{3}{|c|}{ دәqunu su!̣วuелg } & \multirow{2}{*}{\multicolumn{3}{|c|}{ 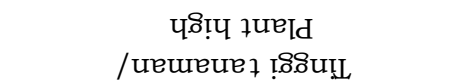 }} & \\
\hline & & & & surełeq 7!!!T & & & sureqeo ṭ.8น & & & ueqеo че [ш & & & & & \\
\hline
\end{tabular}

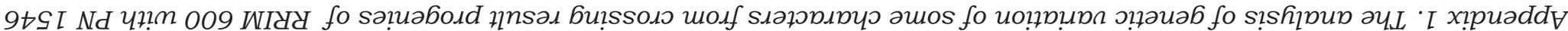

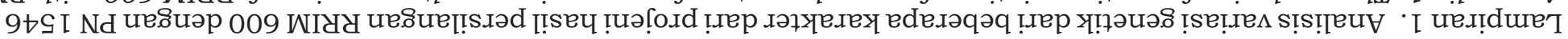




\begin{tabular}{|c|c|c|c|c|c|c|c|c|c|c|c|c|}
\hline $000^{6} \mathrm{I}$ & $000^{\prime} 0$ & $6 \varepsilon 0^{\prime} 0$ & $9 \varepsilon 0^{\prime} \mathrm{I}$ & $68 t^{\prime} \mathrm{I}$ & $\varepsilon \angle 9^{\circ} \varepsilon L$ & Oカt $0^{-}$ & 09L'G- & $\varepsilon \varepsilon 8^{\prime} I^{-}$ & 6SLEOS'Z & I $\angle S^{\prime} 8 Z$ & $0 \varepsilon L ' 8 \subseteq$ & $O t$ \\
\hline$s \varepsilon 9^{`} \mathcal{E}^{-}$ & 08 I $^{\prime} \mathrm{O}^{-}$ & $\mathrm{It} \mathrm{I}^{\prime} \mathrm{O}^{-}$ & L乙が0 & $690^{\circ} \triangleright Z^{-}$ & $9 \varepsilon 6^{\circ} 6 乙$ & $\varepsilon 68^{\prime} 0^{-}$ & $\varepsilon L S^{\prime} L^{-}$ & 乙乙L'E- & 8IZL8‘I & L LS'9 I & s I 6'Et & $6 \varepsilon$ \\
\hline$\angle t 0^{\circ} Z^{-}$ & 8 I I'O- $^{-}$ & $080^{\circ} 0^{-}$ & [9L‘0 & $926^{6} 6^{-}$ & $0 \triangleright I ' \nabla S$ & Ott'0- & 09L'S- & EE8 ' I- & 88 ISL'I & $98 Z^{6} \triangleright I$ & $\varepsilon 60^{\prime} I t$ & $\angle \varepsilon$ \\
\hline sEs' $\mathrm{C}^{-}$ & $\angle E I^{\prime} 0^{-}$ & $860^{\circ} 0^{-}$ & $\varepsilon\left[L^{\prime} O\right.$ & I I6' I I- & E†L'OS & Oカt‘' & 09L'G- & EE8 ' I- & 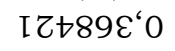 & $000^{‘} Z I^{-}$ & 乙๖9‘8 & $9 \varepsilon$ \\
\hline$\angle t Z^{\prime} \varepsilon^{-}$ & S9I'0- & $9 乙$ I 'O- $^{\prime}$ & $\varepsilon 6 t^{\circ} 0^{-}$ & sEO‘Z9- & 乙E્`SE- & $E L L^{\prime} 0^{-}$ & E60'L- & 乙てて`と'- & Z8L乙I'0- & 6てオ'Iて- & $866^{\circ} Z^{-}$ & $\varepsilon \varepsilon$ \\
\hline s9Z‘て- & $\angle Z I^{\prime} 0^{-}$ & $880^{\circ} 0^{-}$ & I $\varepsilon \varepsilon^{\prime} 0$ & $Z 6 L^{\prime} \angle Z^{-}$ & $\angle 99^{\prime} \varepsilon Z$ & $000^{6} \mathrm{I}$ & $000^{‘} 0$ & $\angle 9$ I't & $6 \varepsilon 99 \varsigma 乙^{\prime} \varepsilon$ & Ls8‘ Zt & $\angle 9 \varepsilon^{\prime} 9 L$ & IE \\
\hline$s \varepsilon Z^{\prime} \triangleright$ & $\varepsilon 0 乙^{\prime} 0^{-}$ & S9I'0- & 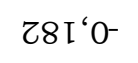 & $z \varepsilon I$ I $6 t$ & IS6`ZI- & $\varepsilon \varepsilon \varepsilon^{\prime} 0$ & $\angle 99^{\prime} Z^{-}$ & $68 \varepsilon^{\prime} I$ & $6696 \angle 8^{\prime} 0$ & $98 Z^{‘} Z^{-}$ & sE9`o乙 & $0 \varepsilon$ \\
\hline$\triangleright Z 6^{\circ} 0^{-}$ & $\mathrm{S} \angle O^{\circ} \mathrm{O}^{-}$ & $980^{\circ} 0^{-}$ & ZSI'0 & $9 \varepsilon \tau^{\prime} \mathrm{S} \mathcal{E}^{-}$ & $8 Z 8^{\circ} \mathrm{OI}$ & $000^{\prime} 0$ & 000‘ & $000^{\prime} 0$ & 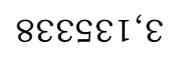 & I $\angle S^{\prime} \mathrm{O} t$ & $S \pitchfork S^{\prime} \varepsilon L$ & $6 Z$ \\
\hline $289^{\prime} \mathrm{Z}$ & $990^{\prime} 0$ & tOI'0 & $88 I^{\prime \prime} 0$ & $\angle \downarrow L^{`} \varepsilon \mathcal{E}^{-}$ & $9 \angle \varepsilon^{\prime} \varepsilon I$ & $000^{\prime} 0$ & 000‘ & $000^{\prime} 0$ & $8 L Z \operatorname{ISS}^{\prime} \varepsilon$ & $t I L^{\prime} \angle t$ & $\varepsilon 9 \varepsilon^{\prime} z 8$ & $8 Z$ \\
\hline$I \sqcup Z^{\prime} \varepsilon^{-}$ & s9I'0- & $9 Z I^{\prime} 0^{-}$ & $\angle Z O^{\circ} O^{-}$ & 089‘てち & I I6' I- & $\varepsilon 68^{\circ} 0^{-}$ & $\varepsilon \angle S^{\prime} L^{-}$ & $Z Z L^{\prime} \mathcal{E}^{-}$ & I†Z96ฑ'I & $6 て{ }^{\prime} 6$ & $\angle 60^{\circ} \mathrm{SE}$ & $\angle Z$ \\
\hline OOI'OI- & IE口"0- & $26 \varepsilon^{\prime} 0^{-}$ & $\angle Z 8^{\circ} 0^{-}$ & IE6‘SL- & I L 8‘89- & $\varepsilon \angle L^{\prime} 0^{-}$ & $\varepsilon 60^{\prime} L^{-}$ & $Z Z \nearrow^{\prime} \varepsilon^{-}$ & IZヤ89と'0 & $000^{\prime} \mathrm{ZI}^{-}$ & $z \vdash 9^{\prime} 8$ & $\mathrm{~s} z$ \\
\hline 009' I- & IOI'O- & $290^{\circ} 0^{-}$ & $\angle \mathcal{E} \mathcal{E}^{\prime} \mathrm{O}^{-}$ & ع8S'S '- & $266^{`} \varepsilon z^{-}$ & $\angle O I^{\prime} O^{-}$ & L乙t‘ & カtヤ‘ $0^{-}$ & 8IZL8“I & ILS'9 I & s I6'Et & $t \tau$ \\
\hline $900^{‘} Z^{-}$ & $\angle I I^{\prime} 0^{-}$ & $8 \angle 0^{\circ} 0^{-}$ & $600^{\prime} 0$ & I6I'I & $\angle E 9^{`} 0$ & $\angle 99^{\circ} 0^{-}$ & $\angle 99^{\circ} 9^{-}$ & $8 L L^{‘} Z^{-}$ & ItZ96t'I & $6 Z t ‘ 6$ & $\angle 60^{\prime} \mathrm{SE}$ & oz \\
\hline$\angle t L^{\prime} O^{-}$ & $890^{\circ} 0^{-}$ & $620^{\circ} 0^{-}$ & $698^{\prime} 0$ & $6 S t^{\prime} S^{-}$ & E8L'L9 & $\angle Z Z^{\prime} O^{-}$ & $206^{\prime} t^{-}$ & $t ヤ 6^{\circ} 0^{-}$ & $6 \mathrm{~S} \angle E O \mathrm{~S}^{\prime} \mathrm{Z}$ & I $\angle S^{`} 8 Z$ & $0 \varepsilon L^{‘} 8 \mathrm{~S}$ & $6 I$ \\
\hline s90‘s- & $9 \varepsilon 乙^{\prime} 0^{-}$ & $\angle 6 I^{\circ} \mathrm{O}^{-}$ & $8 Z 9^{\circ} 0^{-}$ & $\downarrow Z s^{\prime} \varepsilon 9^{-}$ & $08 S^{\prime} \angle \mathcal{E}^{-}$ & $\varepsilon 68^{\circ} 0$ & $\angle Z \nabla^{\circ} 0^{-}$ & ZZL'E & 乙[8カで0 & $98 Z^{‘} \pitchfork I^{-}$ & $078 ` \mathrm{~s}$ & $8 \mathrm{I}$ \\
\hline ZIZ'S- & I七乙'0- & $\mathrm{ZOZ} \mathrm{C}^{\prime} \mathrm{O}^{-}$ & $969^{\circ} 0^{-}$ & ILt'OL- & $69 t^{\prime} 6 t$ & $\angle Z Z^{\prime} 0$ & $\varepsilon 60^{`} \varepsilon^{-}$ & $t \downarrow 6^{\circ} 0$ & 乙I8カでて & †L L'EZ & †EL'乙S & $\angle I$ \\
\hline 6S6‘I & $\angle E O^{\prime} 0$ & $9 \angle 0^{‘} 0$ & $\angle E L^{\prime} O^{-}$ & $80 Z^{\prime} Z L^{-}$ & てカt‘てs- & $\angle Z Z^{\prime} 0$ & $\varepsilon 60^{`} \varepsilon^{-}$ & $t \succ 6^{\circ} 0$ & ItZ96t'I & $6 Z$ & L60‘SE & $9 \mathrm{I}$ \\
\hline 9LL'L- & I & $\mathrm{ZOE} \varepsilon^{\prime} \mathrm{O}^{-}$ & †6 I'0- & $879^{\prime} 6 t$ & $008^{`} \varepsilon I^{-}$ & $\varepsilon \varepsilon \varepsilon^{\prime} 0^{-}$ & $\varepsilon \varepsilon \varepsilon^{\prime} \varsigma^{-}$ & $68 \varepsilon^{\prime} \mathrm{I}^{-}$ & $6696 \angle 8^{\prime} 0$ & $98 Z^{\prime} Z^{-}$ & sE9‘o乙 & SI \\
\hline $9 \angle 9^{6} \mathrm{I}$ & $970 ‘ 0$ & $990^{\prime} 0$ & $\triangleright 乙 \nearrow^{\prime} 0$ & $8 \subseteq \nearrow^{6} 乙 \mathcal{E}^{-}$ & †Z6`S I & $\angle Z Z^{\prime} 0^{-}$ & $206^{\prime} t^{-}$ & $\neg ヤ 6^{\circ} 0^{-}$ & $6 S t \varepsilon 8 \varepsilon^{\prime \prime} 乙$ & $98 乙^{\prime} 9 乙$ & 806، & $\downarrow I$ \\
\hline$Z I \varepsilon^{\prime} \varepsilon^{-}$ & $\angle 9 I^{\circ} 0^{-}$ & $6 Z I^{\prime} 0^{-}$ & I $\varepsilon \varepsilon^{\prime} 0$ & $Z 6 L^{\prime} \angle Z^{-}$ & $\angle 9 S^{\prime} \varepsilon Z$ & 099'0- & $0 † \nearrow^{\prime} 9^{-}$ & $\varepsilon \varepsilon \varepsilon^{\prime} \tau^{-}$ & I & $000^{\circ} 0$ & LSt'E乙 & $\varepsilon I$ \\
\hline 90 I $^{\circ} 0^{-}$ & $\varepsilon \mapsto 0^{`} 0^{-}$ & $\dashv 00^{\circ} 0^{-}$ & †9 I' $\mathrm{O}^{-}$ & $28 \varepsilon^{\prime} 8 t$ & $\angle \angle 9^{6} \mathrm{II}^{-}$ & $000^{6} \mathrm{I}^{-}$ & $000 ‘ 8-$ & $\angle 9 I^{\prime} \nabla$ & 6ع9S9乙'I & $\angle S 8^{\prime} \triangleright$ & $\varepsilon S t^{\prime} 6 乙$ & $Z I$ \\
\hline$\angle \nabla \sigma^{\circ} \varepsilon^{-}$ & Z6I'0- & ESI'0- & $Z \triangleright \nearrow^{\prime} 0^{-}$ & EL9'IS- & $\angle 6 I^{\prime} \angle I^{-}$ & $\varepsilon 68^{\circ} 0^{-}$ & $\varepsilon \angle S^{\prime} L^{-}$ & $Z Z L^{`} \mathcal{E}^{-}$ & 8IZL8“I & L $\angle S^{\prime} 9 \mathrm{I}$ & sI6‘ct & I I \\
\hline †Z०‘9- & $\varepsilon \angle 乙^{\prime} 0^{-}$ & $\downarrow \varepsilon 乙^{\prime} 0^{-}$ & $0 \triangleright 6^{\circ} 0^{-}$ & st9‘08- & 6L8'99- & 099'0- & $0 \sqcup 乙^{\prime} 9^{-}$ & $\varepsilon \varepsilon \varepsilon^{\prime} \tau^{-}$ & I- $^{-}$ & $000^{`} 8 \varepsilon^{-}$ & $\angle S \nabla^{6} \varepsilon Z^{-}$ & $\mathrm{s}$ \\
\hline ES9“' - & $89 乙^{6} 0^{-}$ & $\mathrm{OZZ}^{\circ} \mathrm{O}^{-}$ & $226^{\circ} 0^{-}$ & $106^{\circ} 6 \mathrm{~L}^{-}$ & 909‘99- & $099^{\circ} 0^{-}$ & $0 † 乙^{\prime} 9^{-}$ & $\varepsilon \varepsilon \varepsilon^{\prime} 乙^{-}$ & $t 0 s^{\circ} 0^{-}$ & I $\angle S^{\prime} 8 Z^{-}$ & LI8'I I- & $\bar{z}$ \\
\hline Ч & $(\%) \mathrm{dH}$ & $(\%) \mathrm{dW}$ & Ч & $(\%) \mathrm{dH}$ & $(\%) \mathrm{dW}$ & Ч & $(\%) \mathrm{dH}$ & $(\%) \mathrm{dW}$ & $\mathrm{Y}$ & $(\%) \mathrm{dH}$ & $(\%) \mathrm{dW}$ & \\
\hline
\end{tabular}

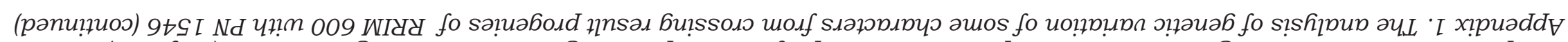

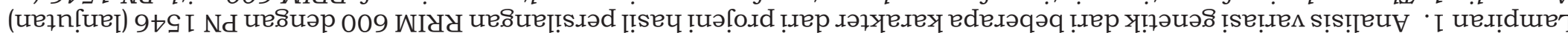

